\title{
EXPLOSIVE ISOMETRIC MUSCLE FORCE OF DIFFERENT MUSCLE GROUPS OF CADET JUDO ATHLETES IN FUNCTION OF GENDER
}

\author{
Stefan Marković ${ }^{1}$, Milivoj Dopsaj ${ }^{2}$, Stevan Jovanović ${ }^{3}$, Tijana Rusovac $^{1}$, Nataša Cvetkovski $^{1}$ \\ ${ }^{1}$ University of Belgrade, Faculty of Sport and Physical Education, student DAS, Belgrade, Serbia \\ ${ }^{2}$ University of Belgrade, Faculty of Sport and Physical Education, Belgrade, Serbia \\ ${ }^{3}$ University of Niš, Faculty of Sport and Physical Education, Niš, Serbia
}

\begin{abstract}
The aim of this paper is to determine the differences in general and specific explosive isometric muscle force in male and female cadet judo athletes. The results of the measured contractile characteristics were obtained by application of a standardized test battery using the isometric dynamometry method for the following five muscle groups: flexor muscles of the left (ŠL) and the right hand (ŠD), back (MRT) and leg extensor muscles (NOGE) and the ankle joint plantar flexor muscles (LIST). The testing included a sample of 14 participants who were competing in the system of individual national championship of the Republic of Serbia for the given age category. On the basis of the obtained results, it can be argued that a general, statistically significant, difference exists between tested judo athletes in the function of gender, both for the absolute values of the variables of basic and specific explosive isometric muscle force (Wilks' Lambda Value 0.000, $\mathrm{F}=898.61, \mathrm{p}=0.000$ ), as well as between the partialized (relative) values of the measured variables (Wilks' Lambda Value $0.001, \mathrm{~F}=325.71, \mathrm{p}=0.000$ ). The highest level of difference between male and female athletes in relation to the absolute values of the obtained results was determined for the variables of the specific explosive isometric muscle force of the left hand flexor muscles (RFD _ $\breve{S} L, p=0.001$ ), leg extensor muscles (RFD $\quad$ NOGE, $p=0.003$ ) and right hand flexor muscles $\left(\mathrm{RFD}_{\max } \mathrm{S} \mathrm{D}, \mathrm{p}=0.005\right)$. In relation to the relative values obtained by partialization of absolute values in relation to skeletal muscle mass (SMM) the highest level of difference was determined for variables of specific isometric explosive muscle force for the left and the right hand, respectively $\left(\mathrm{RFD}_{\max } \breve{S}_{\mathrm{SMM}}, \mathrm{p}=0.000 ; \mathrm{RFD}_{\max } \breve{S}_{\mathrm{SMM}}, \mathrm{p}=0.003\right.$ ). The summarized value of the gender dimorphism index (IPD) is at the level of 71.55 and $53.09 \%$ for both absolute basic (RFDF ${ }_{\text {max }}$ ) and specific $\left(\mathrm{RFD}_{\max }\right.$ ) explosive isometric muscle force, respectively. This indicates that the tested girls reached $71.55 \%$ and $53.09 \%$ of the given contractile characteristics compared to the tested boys. However, when the measured variables are partialized relative to the skeletal muscle mass (SMM), the fore mentioned differences are lowered to $101.98 \%$ and $71.58 \%$, respectively. On general level, the obtained results have shown that there are methodological indications of scientific justification in relation to the partialization of the results of explosive isometric muscle force as a measure of development of contractile muscle potential directly responsible for the intensive manifestation of muscle force in the unit of time, in relation to skeletal muscle mass.
\end{abstract}

Key words: JUDO/ CADETS/ ISOMETRIC DYNAMOMETRY/ EXPLOSIVE ISOMETRIC MUSCLE FORCE

\section{INTRODUCTION}

Judo is an Olympic martial sport in which the performance is determined by the optimal integration of various components of the athlete's preparation that are jointly manifested in the changing conditions of the competition. It can be described as a high-intensity sport, in which athlete attempts to throw his opponent on the back or control him during groundwork combat (Franchini et al., 2007). According to the applicable Judo rules we can distinguish several age categories where in the system of long-term athletes development, and in the system of the selection of perspective athletes, the cadet and junior age categories are distinguished in their importance, while the significance of the senior age category is primarily in the materialization of the maximal competitive performance through 
the achievement of results in competitions of international significance. In each of the age categories, competitors are further divided into clearly defined weight categories, which is common in martial sports disciplines. Within the overall development of their competitive capacities, in order to be successful at international competitions, judo athletes during their training must achieve an exceptional level of physical preparedness (Franchini et al., 2011) where, from a physiological point of view, anaerobic power and capacity, aerobic power and muscle strength/power are considered the main abilities to be developed in judo competitors (Thomas et al., 1989). Consequently, these characteristics were in the primary focus of previous research.

An analysis of judo fighting points to the differences in the manifestation of muscle force and power among judo athletes of different weight categories (Franchini \& Sterkowicz, 2000). This specificity further influences tactical setting of the match and the dominance of use of particular techniques, or groups of techniques specific to each of the weight categories. However, the undeniable fact is that the optimal level of development of the dimensions of isometric muscle force largely determines the competition performance, whereby explosive isometric muscle force (RFD - rate of force development) can be singled out as one of the important predictors of competition performance (Monteiro, 2016; Monteiro et al., 2011). Although modalities of muscle force and power have been in focus of a large number of papers (Detanico et al., 2012; Franchini et al., 2011), regardless of the age category, there is a lack of available data considering basic and specific explosive isometric muscle force. Considering the fact that a sports career is a multi-year process aimed at achieving maximum results, within which three main stages with the corresponding sub stages can be distinguished (Koprivica, 2013), and considering the fact that cadet age is consistent with the first stage of the development of a sports career - basic preparation stage, it can be concluded that at this age it is necessary to provide all conditions for the unobstructed and multidimensional development of the psycho-physical potential of the athlete as a precondition for later specialization. Cadet age is also characteristic because of the phenomenon of accelerated biological development which, due to the specificity of the growth of each individual, causes the heterochronism of biological development in general, as well as the heterochronism of the development of different abilities, from both the aspect of the age and the gender aspect. In the modern concept of the technology of development of a top athlete, along with the course of the selection process, the process of testing and evaluation of the obtained results in relation to the standards established for each individual age and competitive level should start and run (Koprivica, 2013; Dopsaj, 2015). It is also necessary to point out the fact that the positive impact of systematic training on the morphological characteristics and motor skills of children involved in judo sport is documented even in younger age categories (Ilić et al., 2012), so in this respect early involvement of children in systematic judo training can be considered justified and even desirable.

In accordance with the previous, this paper presents one of the initial quantitative research aimed at defining the descriptive characteristics as well as the parameters of the differences in the explosive isometric muscle force in systematically trained and selected cadet age category judo athletes, both from the aspect of absolute and from the aspect of values partialized in relation to skeletal muscle mass (SMM). Partialization of the results was enabled by the application of a new methodology for measuring the body composition of the participants using the InBody 720 system, which operates on the measurement principle of multichannel multisegmental bioelectric impedance (Dopsaj et al., 2015).

The secondary aim of this research consists in obtaining the initial values of the measured contractile characteristics, which can serve as initial standard values in the function of evaluation and defining qualitative assessments of a given level of preparedness of tested athletes. This will significantly contribute to the increase of the knowledge base in the system of long-term sport preparation of young judo athletes, i.e. it will improve the existing technology of sports preparation in judo sport.

\section{METHODS}

The method used in this research was laboratory testing. All data sampling was performed by dynamometry method, using tensiometric probes. 


\section{The research sample}

The research sample in this study consisted of 14 cadet age judo athletes, of which 10 boys and 4 girls.
The basic descriptive characteristics of the sample are shown in Table 1.

Table 1. Basic descriptive characteristics of examined subsamples in relation to gender

\begin{tabular}{|c|c|c|}
\hline & Boys & Girls \\
\hline Age (years) & $15.5 \pm 0.7$ & $16.4 \pm 0.1$ \\
\hline $\mathrm{BH}(\mathrm{cm})$ & $174.6 \pm 4.6$ & $159.7 \pm 7.8$ \\
\hline BW (kg) & $65.9 \pm 7.0$ & $55.7 \pm 11.9$ \\
\hline $\mathrm{BMI}\left(\mathrm{kg} \cdot \mathrm{m}^{-2}\right)$ & $21.68 \pm 2.70$ & $21.7 \pm 3.56$ \\
\hline $\mathrm{PBF}(\%)$ & $3.32 \pm 0.92$ & $11.14 \pm 7.55$ \\
\hline PSMM (\%) & $54.66 \pm 1.42$ & $49.99 \pm 3.81$ \\
\hline Training experience (years) & $3.9 \pm 2.7$ & $3.17 \pm 0.62$ \\
\hline Training frequency (training sessions per week) & $4.0 \pm 0.5$ & $4.0 \pm 0.5$ \\
\hline Weekly training volume $(\mathrm{min})$ & $420 \pm 30$ & $420 \pm 30$ \\
\hline
\end{tabular}

All subjects were members of Judo team "Vinča" and were competing in Republic of Serbia system of national championship for cadet age category. Of the overall sample, two participants were members of Republic of Serbia cadet national team.

\section{Measurement methods}

Testing of muscle force characteristics was performed using dynamometry method, by application of isometric tensiometry, by means of tensiometric probes (Isometrics SMS All4Gym, Belgrade). All tests were performed on University of Belgrade Faculty of sport and physical education in Methodological research laboratory (MIL).

All tests were carried out in the morning (between 09:00 and 11.30 AM) by application of standardized testing procedure and standardized test battery described in previously published literature (Dopsaj

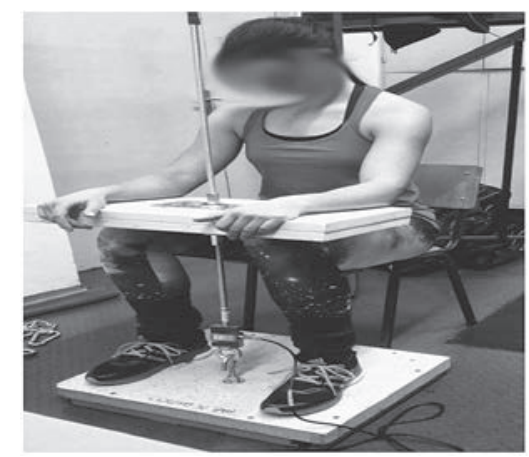

Picture 1. Sitting plantar flexion test (LIST) et al., 2000; Dopsaj et al., 2001; Dopsaj et al., 2004; Dopsaj et al., 2007).

According to the testing procedure requirements, all participants performed 10 minute individual warm-up and stretching. After that the testing was carried out according to the following procedure: The testing procedure was thoroughly explained to the participants. Each subject had two trial attempts performed in high and sub-maximal intensity for the purpose of familiarization with the testing procedure. After having at least 5 min pause, the testing was carried out using trial-to-trial method, where the break between testing attempts was 3 minutes (Tanner \& Gore, 2013).

Better test result was taken for statistical processing. Pictures 1 to 4 show the measurement procedures for the applied test battery.

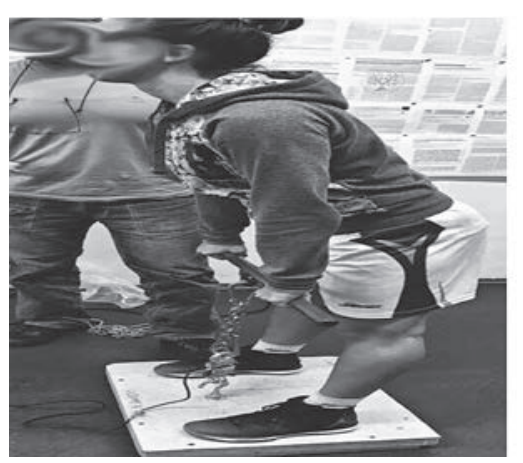

Picture 2. Dead lift test (MRT) 


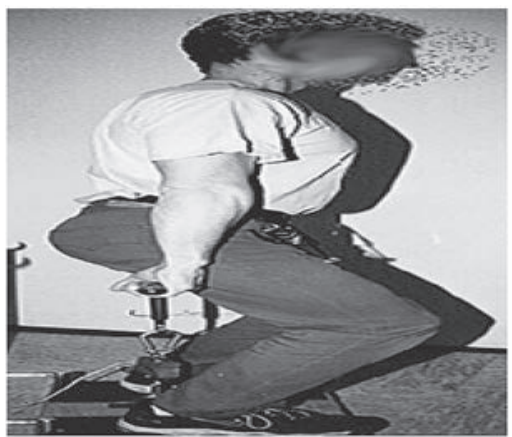

Picture 3. Leg extension test (NOGE)

\section{Variables}

For the purposes of this research contractile characteristics of isometric muscle force were examined from the aspect of intensity of its manifestation. In other words characteristics of explosive muscle force were examined. Explosive muscle force was analyzed in relation to basic $\left(\mathrm{RFDF}_{\max }\right)$ and specific $\left(\mathrm{RFD}_{\max }\right)$ value. All tests were performed on the following muscle groups: flexor muscles of the left (ŠL) and the right hand (ŠD), back extensor muscles (MRT), leg extensor muscles (NOGE) and ankle joint plantar flexors (LIST), by application of following variables:

Following variables were used for the assessment of basic explosive isometric muscle force (basic explosiveness):

- $\mathrm{RFDF}_{\max } \check{\mathrm{S}} \mathrm{L}$ - basic explosive isometric muscle force of flexor muscles of the left hand expressed in $\mathrm{N} / \mathrm{s}^{-1}$

- $\mathrm{RFDF}_{\max -} \check{S} \mathrm{D}^{-}$basic explosive isometric muscle force of flexor muscles of the right hand expressed in $\mathrm{N} / \mathrm{s}^{-1}$

- $\mathrm{RFDF}_{\max }$ MRT - basic explosive isometric muscle force of back extensor muscles expressed in $\mathrm{N} / \mathrm{s}^{-1}$

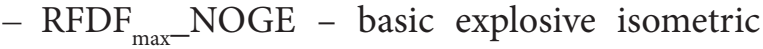
muscle force of leg extensor muscles expressed in $\mathrm{N} / \mathrm{s}^{-1}$

- $\mathrm{RFDF}_{\text {max }}$ LIST - basic explosive isometric muscle force of ankle joint plantar flexors expressed in $\mathrm{N} / \mathrm{s}^{-1}$

Following variables were used for the assessment of specific explosive isometric muscle force (specific explosiveness):

- $\mathrm{RFD}_{\max -} \check{\mathrm{S} L}$ - specific explosive isometric muscle force of flexor muscles of the left hand expressed in $\mathrm{N} / \mathrm{s}^{-1}$

- $\mathrm{RFD}_{\max } \check{S} \mathrm{D}$ - specific explosive isometric mus-

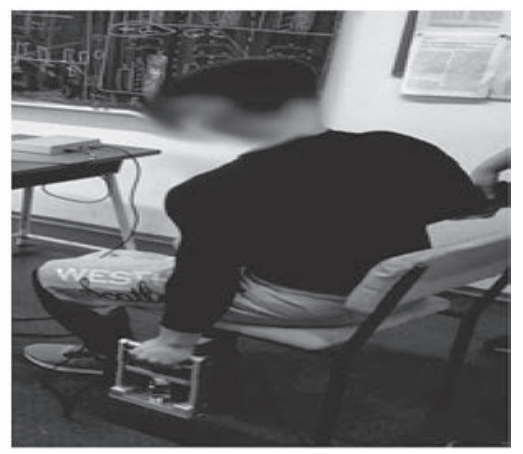

Picture 4. Handgrip test (ŠD/ŠL)

cle force of flexor muscles of the right hand expressed in $\mathrm{N} / \mathrm{s}^{-1}$

- $\mathrm{RFD}_{\max } \mathrm{MRT}$ - specific explosive isometric muscle force of back extensor muscles expressed in $\mathrm{N} / \mathrm{s}^{-1}$

- $\mathrm{RFD}_{\max }$ NOGE - specific explosive isometric muscle force of leg extensor muscles expressed in $\mathrm{N} / \mathrm{s}^{-1}$

- $\mathrm{RFD}_{\max }$ LIST - specific explosive isometric muscle force of ankle joint plantar flexors expressed in $\mathrm{N} / \mathrm{s}^{-1}$

All absolute values of the examined variables were partialized relative to the pure skeletal muscle mass (SMM) in order to obtain relevant data in relation to the used component of the body composition, which is directly responsible for the manifestation of the contractile potential of skeletal muscles. All calculations were performed using the standard calculation formula as follows: VAR_CCrel = VAR_CCmax / SMM, where VAR_CCmax represents the measured value of the isometric explosive muscle force characteristic for the given muscle group, SMM represents skeletal muscle mass expressed in kg, while VAR_ CCrel represents the value of the variable derived.

Both absolute and partialized results of muscle explosiveness, i.e. explosive isometric muscle force, are also shown in the function of gender, that is, they are represented in terms of gender dimorphism, where the gender dimorphism index (IPD) is calculated as a ratio of the given result of the girls relative to the given result of the boys, multiplied by 100 (Dopsaj et al., 2015).

\section{Statistical analysis}

For the purposes of this paper, in the first step of the analysis all raw data obtained by laboratory testing were subjected to descriptive statistical analysis in 
order to define the basic measure of central tendency (MEAN), indicators of data dispersion - standard deviation and coefficient of variation $(\mathrm{SD}, \mathrm{cV} \%)$ and results span indicators - minimum and maximum (MIN, MAX). For the purposes of determining the differences between the tested variables in the function of gender, the methods of multivariate (MANOVA) and univariate (ANOVA) statistical analyses were used. All analyses were carried out using Microsoft Office Excel
2007 and IBM SPSS Statistics v23.0 software packages, while the statistical significance level was defined based on the $95.0 \%$ probability criterion for $\mathrm{p} \leq 0.05$.

\section{RESULTS}

Table 2 shows the descriptive statistics in relation to the tested variables by gender of the participants

Table 2. Basic descriptive indicators of the tested sample in relation to gender

\begin{tabular}{|c|c|c|c|c|c|c|c|c|c|c|}
\hline \multirow{2}{*}{ Variable } & \multicolumn{5}{|c|}{ Boys } & \multicolumn{5}{|c|}{ Girls } \\
\hline & Mean & SD & $\mathrm{cV} \%$ & Min & $\operatorname{Max}$ & Mean & $\mathrm{SD}$ & $\mathrm{cV} \%$ & Min & Max \\
\hline $\mathrm{RFD}_{\max -} \check{\mathrm{S} L}\left(\mathrm{~N} / \mathrm{s}^{-1}\right)$ & 2253.9 & 558.50 & 2.48 & 1776 & 3298 & 990.67 & 51.16 & 5.16 & 953 & 1063 \\
\hline $\mathrm{RFDF}_{\max } \check{S} \mathrm{~L}\left(\mathrm{~N} / \mathrm{s}^{-1}\right)$ & 425.7 & 186.21 & 4.37 & 246.80 & 832.28 & 272.69 & 134.11 & 49.18 & 136.17 & 454.98 \\
\hline $\mathrm{RFD}_{\max } \_\check{\mathrm{S}} \mathrm{D}\left(\mathrm{N} / \mathrm{s}^{-1}\right)$ & 2369.2 & 679.56 & 2.87 & 1779 & 3999 & 1177.33 & 69.21 & 5.88 & 1123 & 1275 \\
\hline $\mathrm{RFDF}_{\text {max }} \check{S} \mathrm{D}\left(\mathrm{N} / \mathrm{s}^{-1}\right)$ & 458.5 & 172.20 & 3.76 & 232.5 & 807.69 & 378.34 & 180.21 & 47.63 & 212.85 & 628.93 \\
\hline $\mathrm{RFD}_{\max -} \mathrm{MRT}\left(\mathrm{N} / \mathrm{s}^{-1}\right)$ & 6231.0 & 3036.07 & 4.87 & 3673 & 13679 & 3322.33 & 386.92 & 11.65 & 2829 & 3774 \\
\hline $\mathrm{RFDF}_{\text {max }}=\operatorname{MRT}\left(\mathrm{N} / \mathrm{s}^{-1}\right)$ & 935.5 & 292.12 & 3.12 & 554.70 & 1364.71 & 585.78 & 162.61 & 27.76 & 446.13 & 813.83 \\
\hline $\mathrm{RFD}_{\max -} \operatorname{NOGE}\left(\mathrm{N} / \mathrm{s}^{-1}\right)$ & 4919.67 & 1390.14 & 2.83 & 3329 & 7425 & 2298 & 272.99 & 11.88 & 1999 & 2659 \\
\hline $\mathrm{RFDF}_{\max -} \mathrm{NOGE}\left(\mathrm{N} / \mathrm{s}^{-1}\right)$ & 1059.57 & 550.35 & 5.19 & 466.4 & 2183.98 & 724.21 & 43.81 & 6.05 & 668.75 & 775.86 \\
\hline $\mathrm{RFD}_{\max } \operatorname{LIST}\left(\mathrm{N} / \mathrm{s}^{-1}\right)$ & 12314.4 & 1821.38 & 1.48 & 9819 & 15997 & 8840.33 & 2627.62 & 29.72 & 5738 & 12163 \\
\hline $\mathrm{RFDF}_{\max } \operatorname{LIST}\left(\mathrm{N} / \mathrm{s}^{-1}\right)$ & 2839.53 & 890.41 & 3.14 & 1834.9 & 5048.1 & 2277.07 & 421.51 & 18.51 & 1856.82 & 2853.32 \\
\hline $\mathrm{RFD}_{\max } \check{S}^{\mathrm{S}} \mathrm{L}_{-\mathrm{SMM}}\left(\mathrm{N} / \mathrm{s}^{-1 \mathrm{kgSMM}}\right)$ & 61.85 & 9.55 & 15.44 & 52.67 & 77.38 & 36.9 & 6.04 & 16.36 & 29.50 & 44.29 \\
\hline $\mathrm{RFDF}_{\max }-\check{\mathrm{S}}_{\mathrm{SMM}}\left(\mathrm{N} / \mathrm{s}^{-1 \mathrm{kgSMM}}\right)$ & 11.60 & 4.47 & 38.5 & 7.03 & 22.02 & 10.65 & 6.16 & 57.9 & 4.22 & 18.96 \\
\hline $\begin{array}{l}\mathrm{RFD}_{\max } \check{S} \mathrm{~S}_{\text {SMM }} \\
\left(\mathrm{N} / \mathrm{s}^{-1 \mathrm{kgSMM}}\right)\end{array}$ & 64.8 & 11.39 & 17.57 & 53.08 & 88.67 & 43.36 & 3.17 & 7.32 & 39.47 & 47.25 \\
\hline $\begin{array}{l}R_{\text {RFF }}{ }_{\text {max }} \check{S}_{\text {SMM }} \\
\left(\mathrm{N} / \mathrm{s}^{-1 \mathrm{kgSMM}}\right)\end{array}$ & 12.73 & 4.60 & 36.15 & 6.62 & 21.89 & 13.22 & 4.53 & 34.28 & 8.87 & 19.47 \\
\hline $\begin{array}{l}\mathrm{RFD}_{\max } \mathrm{MRT}_{\text {SMM }} \\
\left(\mathrm{N} / \mathrm{s}^{-1 \mathrm{kgSMM}}\right)\end{array}$ & 167.75 & 60.73 & 36.2 & 97.17 & 303.30 & 124.91 & 28.66 & 22.94 & 87.59 & 157.25 \\
\hline $\begin{array}{l}\mathrm{RFDF}_{\max -} \mathrm{MRT}_{\text {SMM }} \\
\left(\mathrm{N} / \mathrm{s}^{-1 \mathrm{kgSMM}}\right)\end{array}$ & 25.93 & 7.78 & 30.01 & 16.71 & 40.81 & 22.31 & 8.49 & 38.07 & 13.81 & 33.91 \\
\hline $\begin{array}{l}\mathrm{RFD}_{\text {max }} \mathrm{NOGE}_{\text {SMM }} \\
\left(\mathrm{N} / \mathrm{s}^{-1 \mathrm{kgSMM}}\right)\end{array}$ & 136.42 & 35.25 & 25.84 & 88.07 & 201.22 & 86.34 & 19.96 & 23.12 & 61.89 & 110.79 \\
\hline $\begin{array}{l}\mathrm{RFDF}_{\max } \mathrm{NOGE}_{\mathrm{SMM}} \\
\left(\mathrm{N} / \mathrm{s}^{-1 \mathrm{kgSMM}}\right)\end{array}$ & 28.68 & 12.36 & 43.1 & 14.05 & 49.76 & 27.05 & 4.80 & 17.76 & 20.70 & 32.33 \\
\hline $\begin{array}{l}\mathrm{RFD}_{\max } \mathrm{LIST}_{\mathrm{SMM}} \\
\left(\mathrm{N} / \mathrm{s}^{-1 \mathrm{kgSMM}}\right)\end{array}$ & 341.04 & 25.51 & 7.48 & 295.66 & 375.81 & 319.09 & 69.34 & 21.73 & 221.54 & 376.56 \\
\hline $\begin{array}{l}\text { RFDF }_{\max } \text { LIST }_{\text {SMM }} \\
\left(\mathrm{N} / \mathrm{s}^{-1 \mathrm{kgSMM}}\right)\end{array}$ & 61.85 & 9.55 & 15.44 & 52.67 & 77.38 & 82.8 & 7.86 & 9.49 & 71.69 & 88.38 \\
\hline
\end{tabular}


Table 3 shows the results of analyses of differences (MANOVA \& ANOVA) between the tested groups in the function of gender. Based on the presented results of MANOVA, it can be argued that there is a statistically significant difference between the absolute values of basic and specific explosive isometric muscle force variables (Wilks' Lambda Value 0.000, F = 898.61, $\mathrm{p}=0.000$ ), as well as between the partialized values of the basic and specific explosive isometric muscle force (Wilks' Lambda Value 0.001, F = 325.71, $\mathrm{p}=0.000$ ), for the tested cadet age judo athletes in the function of gender.

The highest level of difference between the male and female athletes in relation to the absolute values was determined for the variables of the specific explosive isometric muscle force of the left hand flex-

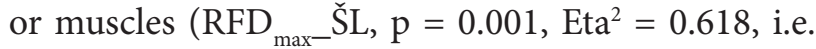
$61.8 \%$ ), for the leg extensor muscles (RFDmaxNO$\mathrm{GE}, \mathrm{p}=0.003$, $\mathrm{Eta}^{2}=0.527$, i.e. $52.7 \%$ ), and for the right hand flexor muscles $\left(\mathrm{RFD}_{\max } \mathrm{S} \mathrm{D}, \mathrm{p}=0.005, \mathrm{Eta}^{2}\right.$ $=0.493$, i.e., $49.7 \%$ ).

In relation to the values of the variables partialized based on the pure contractile tissue, i.e. skeletal muscle mass, the highest level of difference was determined for the variables of the specific explosive isometric muscle force for the left hand $\left(\mathrm{RFD}_{\max } \check{\mathrm{S}}_{\mathrm{SMM}}\right.$, $\mathrm{p}=0.000, \mathrm{Eta}^{2}=0.657$, i.e. $\left.65.7 \%\right)$, for the right hand $\left(\mathrm{RFD}_{\max } \check{S}_{\mathrm{S}_{\text {SMM }}}, \mathrm{p}=0.003, \mathrm{Eta}^{2}=0.523\right.$, i.e. $\left.52.3 \%\right)$, and for leg extensor muscles $\left(\mathrm{RFD}_{\max } \mathrm{NOGE}_{\mathrm{SMM}}, \mathrm{p}=\right.$ $0.022, \mathrm{Eta}^{2}=0.367$, i.e. $36.7 \%$ ), while other variables did not show statistically significant differences.

Table 3. Results of MANOVA and ANOVA for the tested variables in relation to gender

\begin{tabular}{|c|c|c|c|c|c|c|}
\hline \multicolumn{7}{|l|}{ MANOVA - multivariate test } \\
\hline & Effect & Value & $\mathrm{F}$ & $\mathrm{p}$ & $\begin{array}{c}\text { Partial } \\
\text { Eta }^{2}\end{array}$ & $\begin{array}{c}\text { Ob- } \\
\text { served } \\
\text { Power }\end{array}$ \\
\hline Gender - absolute values & Wilks' Lambda & 0.000 & 898.61 & 0.000 & 1.000 & 1.000 \\
\hline Gender - relative values (SMM) & Wilks' Lambda & 0.001 & 325.71 & 0.000 & 0.999 & 1.000 \\
\hline \multicolumn{7}{|c|}{ ANOVA - Test of Between - subjects Effects } \\
\hline & Variable & Mean Square & F value & $\mathrm{p}$ & $\begin{array}{c}\text { Partial } \\
\mathrm{Eta}^{2}\end{array}$ & $\begin{array}{c}\text { Ob- } \\
\text { served } \\
\text { Power }\end{array}$ \\
\hline \multirow{10}{*}{ Gender - absolute values } & $\mathrm{RFD}_{\max -} \check{S} \mathrm{~L}$ & 4559229.6 & 19.44 & 0.001 & 0.618 & 0.981 \\
\hline & $\mathrm{RFDF}_{\max } \check{S}_{\mathrm{S}} \mathrm{L}$ & 66886.0 & 2.19 & 0.164 & 0.154 & 0.276 \\
\hline & $\mathrm{RFD}_{\max }-\mathrm{S} \mathrm{D}$ & 4058854.6 & 11.68 & 0.005 & 0.493 & 0.880 \\
\hline & $\mathrm{RFDF}_{\max } \check{S} \mathrm{D}$ & 18365.1 & 0.61 & 0.452 & 0.048 & 0.111 \\
\hline & $\mathrm{RFD}_{\max -} \mathrm{MRT}$ & 24172405.1 & 3.48 & 0.087 & 0.225 & 0.404 \\
\hline & $\mathrm{RFDF}_{\max } \mathrm{MRT}$ & 349422.4 & 4.95 & 0.046 & 0.292 & 0.534 \\
\hline & $\mathrm{RFD}_{\max }$ NOGE & 19637531.8 & 13.38 & 0.003 & 0.527 & 0.918 \\
\hline & $\mathrm{RFDF}_{\max }-\mathrm{NOGE}$ & 321320.5 & 1.41 & 0.258 & 0.105 & 0.195 \\
\hline & $\mathrm{RFD}_{\max }$ LIST & 34484137.2 & 8.18 & 0.014 & 0.405 & 0.747 \\
\hline & RFDF $_{\max \_ \text {LIST }}$ & 903885.1 & 1.41 & 0.257 & 0.105 & 0.195 \\
\hline \multirow{10}{*}{ Gender - relative values (SMM) } & $\mathrm{RFD}_{\max }=\mathrm{SL}_{\mathrm{SMM}}$ & 1778.5 & 22.95 & 0.000 & 0.657 & 0.992 \\
\hline & $\mathrm{RFDF}_{\max } \check{S}_{\mathrm{SMM}}$ & 2.6 & 0.11 & 0.750 & 0.009 & 0.060 \\
\hline & $\mathrm{RFD}_{\max } \check{S}_{\mathrm{S}} \mathrm{SMM}_{\mathrm{SM}}$ & 1313.8 & 13.17 & 0.003 & 0.523 & 0.914 \\
\hline & $\mathrm{RFDF}_{\max } \check{\mathrm{S}}_{\mathrm{SMM}}$ & 0.7 & 0.03 & 0.858 & 0.003 & 0.053 \\
\hline & $\mathrm{RFD}_{\max }-\mathrm{MRT}_{\mathrm{SMM}}$ & 5244.4 & 1.77 & 0.209 & 0.128 & 0.232 \\
\hline & $\mathrm{RFDF}_{\max } \mathrm{MRT}_{\mathrm{SMM}}$ & 37.4 & 0.59 & 0.457 & 0.047 & 0.109 \\
\hline & $\mathrm{RFD}_{\max } \mathrm{NOGE}_{\mathrm{SMM}}$ & 7166.8 & 6.95 & 0.022 & 0.367 & 0.678 \\
\hline & $\mathrm{RFDF}_{\max } \mathrm{NOGE}_{\mathrm{SMM}}$ & 7.6 & 0.06 & 0.806 & 0.005 & 0.056 \\
\hline & $\mathrm{RFD}_{\max }-\mathrm{LIST}_{\mathrm{SMM}}$ & 1376.9 & 0.82 & 0.384 & 0.064 & 0.132 \\
\hline & RFDF $_{\max }$ LIST $_{S M M}$ & 64.8 & 0.26 & 0.620 & 0.021 & 0.076 \\
\hline
\end{tabular}


The results of the obtained gender dimorphism index (IPD) values in relation to the absolute and partialized (relative) values of the measured explosiveness (basic and specific) for the applied tests are shown in Chart 1 and Chart 2. Based on the obtained absolute values, it can be argued that a greater difference in specific explosiveness between males and females (IPD RFD max $_{\text {maL }}$ AL $53.09 \%$ ) was determined, compared to the level of basic explosiveness (IPD $\mathrm{RFDF}_{\max } \mathrm{ALL}=71.55 \%$ ).

Gender dimorphism index for the absolute values of the results of contractile characteristics

RFDmax \& RFDFmax

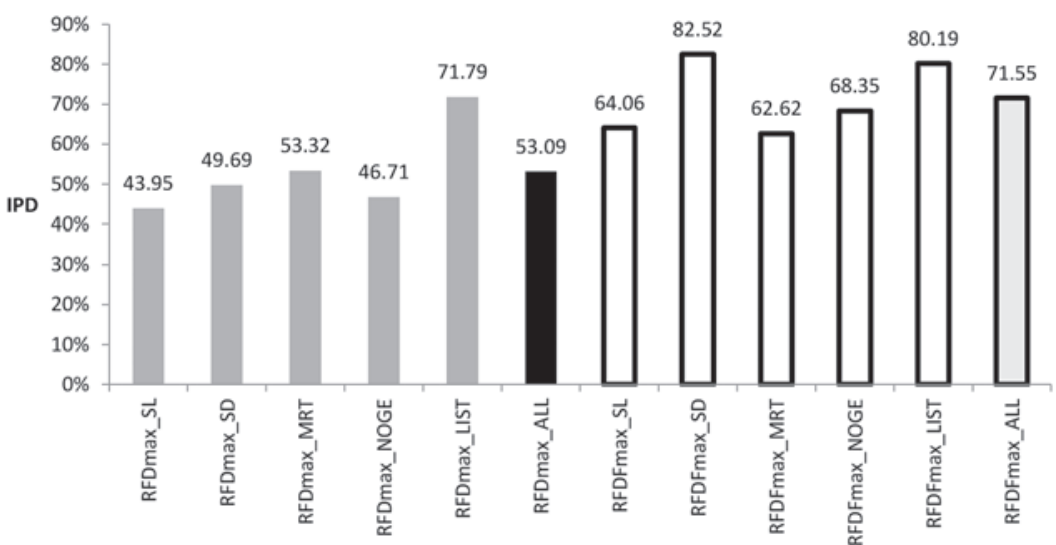

Graph 1. IPD in relation to the absolute values of the explosive isometric muscle force (explosiveness)

As in the case of absolute IPD values (Graph 1), based on the obtained results of the partialized (relative) values of the explosive isometric muscle force (explosiveness) (Graph 2), it can be argued that a greater difference in specific explosiveness between males and females was determined (IPD RFD $\mathrm{ALL}_{\mathrm{SMM}}=71.58 \%$ ) comparing to the basic explosiveness differences (IPD RFDF ${ }_{\text {max }}{ }^{A L L} L_{\text {SMM }}=101.98 \%$ ).

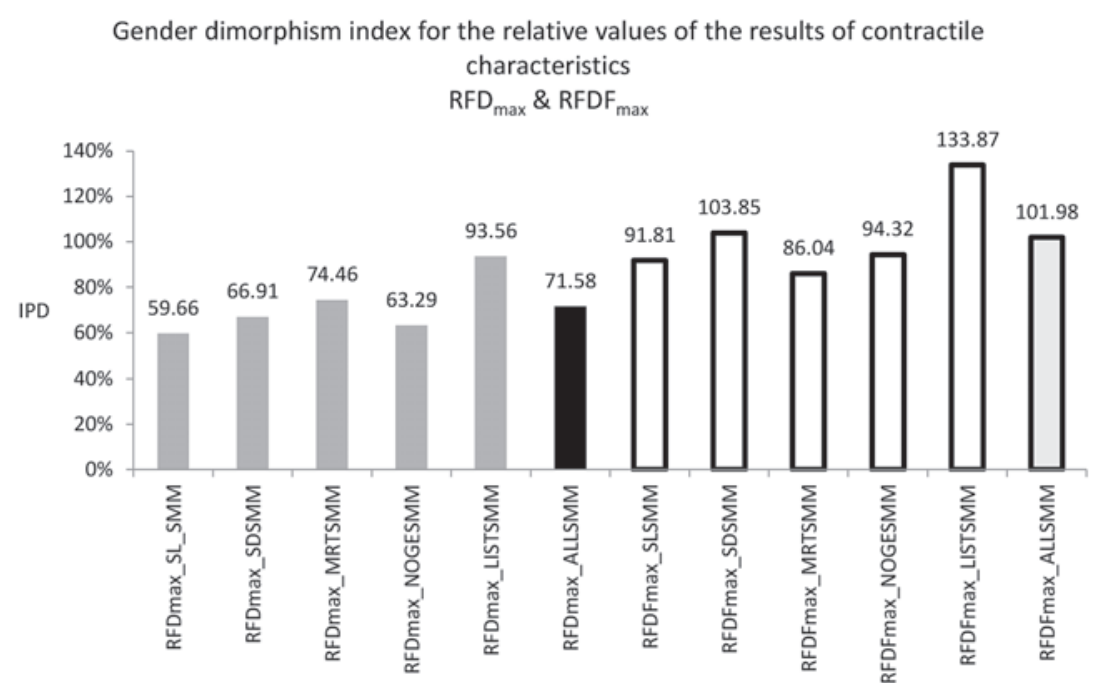

Graph 2. IPD in relation to the partialized (relative) values of the explosive isometric muscle force (explosiveness)

\section{DISCUSSION}

Based on the results of descriptive statistical analysis, it can be concluded that all the measured values of the tested variables are in the acceptable range of variation of results because the coefficient of variation $(\mathrm{cV} \%)$ for the absolute values is in the range of $1.48 \%$ $\left(\mathrm{RFD}_{\max }\right.$ LIST) up to $5.19 \%\left(\mathrm{RFDF}_{\max }\right.$ NOGE) for boys, while in girls it the ranges from $5.16 \%\left(\mathrm{RFD}_{\max }-\right.$ ŠL) up to $49.18 \%\left(\right.$ RFDF $_{\max } \check{S} \mathrm{~L}$ ) (Table 1). Since most 
variables, that is $75.0 \%$ of the variables, have extremely low level of variation, i.e. an extremely high level of homogeneity ( 15 variables have a variation below $10 \%$ or below $30 \%$, for both males and females), while the other $25.0 \%$ have a coefficient of variation below $60.0 \%$, at the general level it can be concluded that the measured results are homogeneous and representative in terms of valid scientific interpretation.

In relation to the achieved levels of development of the basic explosive isometric muscle force, i.e. RFDFvariable, it can be argued that for the boys subsample a maximum average value of 425.70 and 458.51 $\mathrm{N} / \mathrm{s}^{-1}$ has been measured for the left and right hand, respectively. For the girls subsample basic explosive isometric muscle force of the left and right hand at the level of 272.69 and $378.34 \mathrm{~N} / \mathrm{s}^{-1}$ respectively, has been measured (Table 2).

ANOVA has shown that in the case of these results there was no statistically significant difference between the absolute characteristics of the basic explosive isometric muscle force in relation to gender (Table 3, RFDF ${ }_{\max }$ ŠL - F value $=2.19, \mathrm{p}=0.164$; RFD$\mathrm{F}_{\max -\mathrm{S} D}-\mathrm{F}$ value $=0.61, \mathrm{p}=0.452$ ).

If the obtained average value is analyzed in the context of gender dimorphism, it can be argued that the ratio of girls and boys results of the measured variable for the left and right hand is at the level of 64.05 and $82.52 \%$, respectively (Chart 1 ), i.e. the value of the gender dimorphism index (IPD) is at an average level of $73.63 \%$. In other words, the general level of muscle explosiveness of the hand flexor muscles in girls is at about $3 / 4$ of the score achieved by boys.

For the back extensor muscles (Dead lift test), as one of the very important muscle groups from the aspect of judo sport, average $\mathrm{RFDF}_{\text {max }}$ value of 935.49 $\mathrm{N} / \mathrm{s}^{-1}$ in boys subsample and $585.78 \mathrm{~N} / \mathrm{s}^{-1}$ in girls subsample was measured (Table 2). The results of ANOVA have shown that there is a statistically significant difference between the aforementioned absolute characteristics of explosiveness in relation to gender (Table 3, RFDF ${ }_{\max }$ MRT $-\mathrm{F}$ value $=4.95, \mathrm{p}=0.046$ ). The girls achieved a lower level of basic explosiveness by as much as $349.71 \mathrm{~N} / \mathrm{s}^{-1}$, with the achieved IPD level of $62.62 \%$ (Graph 1). In other words, the basic level of muscle explosiveness of the back extensor muscles in girls is at about $2 / 3$ of the results achieved by boys.

The average value of the basic explosive isometric muscle force of the leg extensor muscles was at the level of $1059.57 \mathrm{~N} / \mathrm{s}^{-1}$ in boys and $724.21 \mathrm{~N} / \mathrm{s}^{-1}$ in girls (Table 2). The results of ANOVA have shown that there was no statistically significant difference between the measured explosiveness in relation to gender (Table 3, RFDF $_{\text {max }}$ NOGE - F value $=1.41, \mathrm{p}$ $=0.258)$. As with the back extensor muscles, for the leg extensor muscles it was found that girls achieved a lower score for as much as $335.36 \mathrm{~N} / \mathrm{s}^{-1}$, with IPD level of $68.35 \%$ (Chart 1). For this muscle group, the basic explosiveness of the leg extensor muscles in girls was at the level of about $2 / 3$ in relation to the boys.

For the ankle joint plantar flexor muscles the mean value of basic explosive isometric muscle force at the level of $2839.53 \mathrm{~N} / \mathrm{s}^{-1}$ in boys and $2277.07 \mathrm{~N} / \mathrm{s}^{-1}$ in girls was measured (Table 2). The results of ANOVA have shown that there was no statistically significant difference between the above mentioned absolute characteristics of explosiveness in relation to gender (Table 3, RFDF $_{\max }$ LIST $-\mathrm{F}$ value $=1.41, \mathrm{p}=0.257$ ). For the ankle joint plantar flexor muscles it was found that girls achieved a lower score for $562.46 \mathrm{~N} / \mathrm{s}^{-1}$, with the achieved IPD level of $80.19 \%$ (Chart 1). In case of this muscle group, the result achieved by girls is at the level of about 4/5 in relation to the results found in boys.

In relation to the achieved levels of development of the basic explosive isometric muscle force, but from the aspect of values partialized in relation to the skeletal muscle mass, for the handgrip test the results at the level of 11.60 and $12.73 \mathrm{~N} / \mathrm{s}^{-1 \mathrm{kgSMM}}$ for the boys subsample, and 10.65 and $13.2 \mathrm{~N} / \mathrm{s}^{-1 \mathrm{kgsmM}}$ for the girls subsample were measured, for left and right hand, respectively (Table 2). The results of ANOVA have shown that there is no statistically significant difference between the mentioned relative characteristics of explosiveness in relation to gender (Table 3, RFDFmax_ŠLSMM - F value $=0.10, \mathrm{p}=0.750$; RFDFmax_ ŠDSMM - F value $=0.03, p=0.858$ ). It was found that female subjects for the left hand achieved 0.95 $\mathrm{N} / \mathrm{s}^{-1 \mathrm{kgSMM}}$ lower partialized value of basic explosive isometric muscle force compared to boys, reaching the IPD level of $91.81 \%$, while the partialized values achieved for the right hand grip were $0.49 \mathrm{~N} / \mathrm{s}^{-1 \mathrm{kgSMM}}$ higher than those found in boys, with an IPD level of $103.69 \%$ (Chart 2). These results indicate that after partialization in relation to the pure skeletal muscle mass, i.e. SMM, the gender difference in relation to the basic explosive isometric muscle force of the flexor muscles of the left and right hand is lost, that is, they are in the IPD summarized interval of $97.75 \%$.

For the back extensor muscles (Dead lift test) the measured mean value of $\mathrm{RFDF}_{\max } \mathrm{MRT}_{\mathrm{SMM}}$ in boys was at the level of $25.93 \mathrm{~N} / \mathrm{s}^{-1 \mathrm{kgSMM}}$ while in girls it was 
at the level of $22.31 \mathrm{~N} / \mathrm{s}^{-1 \mathrm{kgSMM}}$. When it comes to leg extensor muscles (Leg extension test), the measured relative value of the basic explosive isometric muscle force was at the level of $28.68 \mathrm{~N} / \mathrm{s}^{-1 \mathrm{kgSMM}}$ in boys and $27.05 \mathrm{~N} / \mathrm{s}^{-1 \mathrm{kgSMM}}$ in girls (Table 2). The results of ANOVA have shown that in both tests there was no statistically significant difference between the aforementioned relative characteristics of explosiveness in relation to gender (Table 3, $\mathrm{RFDF}_{\max -} \mathrm{MRT}_{\mathrm{SMM}}-\mathrm{F}$ value $=0.59, \mathrm{p}=0.457 ; \mathrm{RFDF}_{\max } \mathrm{NOGE}_{\mathrm{SMM}}-\mathrm{F}$ value $=0.6, \mathrm{p}=0.806)$. In this test, the tested girls achieved $3.62 \mathrm{~N} / \mathrm{s}^{-1 \mathrm{kgSMM}}$ lower relative values of the basic explosive isometric muscle force, with the IPD reaching a level of $86.04 \%$, that is, the tested boys in the given test achieved $1.63 \mathrm{~N} / \mathrm{s}^{-1 \mathrm{kgSMM}}$ better result compared to girls, with the IPD of $94.32 \%$, respectively (Chart 2). In this respect, it can be said that for the back extensor muscles, from the aspect of relative values, boys achieved about $1 / 6$ better results than girls, while partialized results for the leg extensor muscles were very similar.

The results of partialized values of the basic explosive isometric muscle force for the ankle joint plantar flexor muscles (Sitting plantar flexion test) showed that this characteristic is at the level of $61.85 \mathrm{~N} / \mathrm{s}^{-1 \mathrm{~kg}-}$ ${ }^{\text {SMM }}$ for the boys subsample and $82.80 \mathrm{~N} / \mathrm{s}^{-1 \mathrm{kgSMM}}$ for the girls subsample (Table 2). The results of ANOVA have shown that there is no statistically significant difference between the aforementioned relative characteristics of explosiveness in relation to gender (Table 3, RFDF $_{\text {max }}$ LIST $_{\text {SMM }}-\mathrm{F}$ value $\left.=0.259, \mathrm{p}=0.620\right) . \mathrm{Nev}-$ ertheless, on this test girls achieved, on average 20.95 $\mathrm{N} / \mathrm{s}^{-1 \mathrm{kgSMM}}$ higher results, with the IPD at the level of $133.82 \%$. In other words, when observed from the aspect of partialized values relative to the skeletal muscle mass (SMM), girls achieved about $1 / 3$ better results than boys on the sitting plantar flexion test.

The achieved level of development of specific explosive isometric muscle force, i.e. variables $\left(\mathrm{RFD}_{\max }\right)$, for the flexor muscles of the hand (Handgrip test) was at the average level of 2253.89 and $2369.22 \mathrm{~N} / \mathrm{s}^{-1}$ in boys and 990.67 and $1177.33 \mathrm{~N} / \mathrm{s}^{-1}$ in girls, for the left and right hand, respectively (Table 2). In relation to the partialized values the achieved results were at the level of 61.85 and $64.80 \mathrm{~N} / \mathrm{s}^{-1}$ in boys and 36.90 and $43.36 \mathrm{~N} / \mathrm{s}^{-1}$ in girls, for the left and right hand, respectively (Table 2). The results of ANOVA have shown that a statistically significant difference exists between the aforementioned characteristics of explosiveness in relation to gender for the absolute as well as for the partialized values of the obtained results (Table $3, \mathrm{RFD}_{\text {max }} \check{S} \mathrm{~S} \mathrm{~L}-\mathrm{F}$ value $=19.44, \mathrm{p}=0.001 ; \mathrm{RFD}_{\max }{ }_{-} \mathrm{S} \mathrm{D}$ - $\mathrm{F}$ value $=11.68, \mathrm{p}=0.005 ; \mathrm{RFD}_{\max }-\check{S}_{\mathrm{SMM}}-\mathrm{F}$ value $=22.949, \mathrm{p}=0.000 ; \mathrm{RFD}_{\max }-\check{S}_{\mathrm{SMM}}-\mathrm{F}$ value $=13.17$, $\mathrm{p}=0.003$ ). Based on the presented results, it was found that the boys achieved $1263.22 \mathrm{~N} / \mathrm{s}^{-1}$ better results for the left hand, i.e. $1191.89 \mathrm{~N} / \mathrm{s}^{-1}$ for the right hand, and that the IPD value was $43.95 \%$ and $49.69 \%$, respectively. In this respect, it can be said that the results achieved by boys are more than twice higher than the results achieved by girls.

For the back extensor muscles (Dead lift test) specific explosive isometric muscle force mean value at the level of $6231.00 \mathrm{~N} / \mathrm{s}^{-1}$ and $3322.33 \mathrm{~N} / \mathrm{s}^{-1}$ was measured for the boys and girls subsample, respectively (Table 2). The results of ANOVA have shown that there was no statistically significant difference between the absolute characteristics of explosiveness in relation to gender (Table $3, \mathrm{RFD}_{\max -} \mathrm{MRT}$ - F val$\mathrm{ue}=3.48, \mathrm{p}=0.087$ ), that is, the difference is at the boundary level for the $90.0 \%$ probability. The absolute mathematical difference of the measured results of the given variable of $2908.67 \mathrm{~N} / \mathrm{s}^{-1}$ in favor of the boys, and the IPD value of $53.31 \%$ indicates that in the case of this muscle group, boys achieved approximately double the results compared to girls.

For the leg extensor muscles (Leg extension test) the measured mean value of specific explosive isometric muscle force is at the level of $4919.67 \mathrm{~N} / \mathrm{s}^{-1}$ and $2298.00 \mathrm{~N} / \mathrm{s}^{-1}$ for boys and girls, respectively (Table 2). The results of ANOVA have shown that there is a statistically significant difference between the aforementioned absolute characteristics of explosiveness

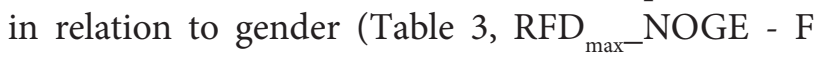
value $=13.38, \mathrm{p}=0.003)$. From the aspect of absolute indicators, the boys on average achieved $2621.67 \mathrm{~N} / \mathrm{s}^{-}$ ${ }^{1}$ better results, with the IPD at the level of $46.71 \%$. In other words, in this case, the difference achieved indicates about twice the better results in boys.

For the ankle joint plantar flexor muscles (Sitting plantar flexion test) the measured mean value of specific explosive isometric muscle force was at the level of $12314.40 \mathrm{~N} / \mathrm{s}^{-1}$ in boys and $8840.33 \mathrm{~N} / \mathrm{s}^{-1}$ in girls (Table 2). The results of ANOVA have shown that there is a statistically significant difference between these results (Table 3, $\mathrm{RFD}_{\max }$ LIST - F value $=8.183$, $\mathrm{p}=0.014$ ). Girls achieved a lower level of absolute value of specific explosive isometric muscle force for 
$3474.07 \mathrm{~N} / \mathrm{s}^{-1}$, with the achieved IPD level of $71.78 \%$ (Graph 1). In other words, the achieved $\mathrm{RFD}_{\max }$ values for the girls subsample were $2 / 3$ of the values achieved by boys.

For the back extensor muscles (Dead lift test) the mean partialized value of specific explosiveness at the level of $167.75 \mathrm{~N} / \mathrm{s}^{-1 \mathrm{kgSMM}}$ was measured in boys, while for the girls measured mean value was at the level of $124.91 \mathrm{~N} / \mathrm{s}^{-1 \mathrm{kgSMM}}$ (Table 2). The results of ANOVA have shown that there was no statistically significant difference in relation to gender (Табела $3, \mathrm{RFD}_{\text {max- }}$ $\mathrm{MRT}_{\text {SMM }}-\mathrm{F}$ value $=1.765, \mathrm{p}=0.209$ ), although girls of a given age achieved a lower level of specific explosiveness for $42.84 \mathrm{~N} / \mathrm{s}^{-1 \mathrm{kgSMM}}$, with the achieved IPD level of $74.45 \%$ (Chart 2). The specific level of explosiveness of the back extensor muscles partialized in relation to the skeletal muscle mass (SMM) found in girls was at about $3 / 4$ of the results measured in boys.

For the leg extensor muscles (Leg extension test) partialized value of specific explosiveness in boys was at the level of $136.42 \mathrm{~N} / \mathrm{s}^{-1 \mathrm{kggMM}}$, while for the girls it was at the level of $136.42 \mathrm{~N} / \mathrm{s}^{-1 \mathrm{kgSMM}}$ (Table 2). A statistically significant difference was found between these results (Table 3, $\mathrm{RFD}_{\text {max }} \mathrm{NOGE}_{\mathrm{SMM}}-\mathrm{F}$ value $=6.95$, $\mathrm{p}=0.022$ ). As in the case of back extensor muscles, for the leg extensor muscles girls achieved lower relative value of a given variable for $50.08 \mathrm{~N} / \mathrm{s}^{-1 \mathrm{kgSMM}}$ with the achieved IPD value of $63.29 \%$ (Chart 2). In the case of this muscle group, the relative value of specific explosiveness in girls was approximately $2 / 3$ relative to the results measured in boys.

The average value of the specific explosive isometric muscle force of the ankle joint plantar flexor muscles (Sitting plantar flexion test) was $341.04 \mathrm{~N} / \mathrm{s}^{-1 \mathrm{kggMM}}$ in boys, and $319.09 \mathrm{~N} / \mathrm{s}^{-1 \mathrm{kgSMM}}$ in girls (Table 2). There was no statistically significant difference between these relative explosiveness characteristics in relation to gender (Table 3, RFD ${ }_{\text {max }}$ LIST $_{\text {SMM }}$ - F value $=0.815$, $\mathrm{p}=0.384$ ). The girls achieved a $21.95 \mathrm{~N} / \mathrm{s}^{-1 \mathrm{kgSMM}}$ lower value, with the achieved IPD level of $93.56 \%$ (Graph 2 ). However, in the case of this muscle group, the average value of the relative level of specific explosiveness of the ankle joint plantar flexor muscles in girls was very similar to the values found in boys.

On the basis of all of the fore mentioned, it can be concluded that, in all tested muscle groups, boys have significantly higher absolute values of basic explosive isometric muscle force than girls. The results of this study have shown that IPD values range from $62.62 \%$ for the back extensor muscles up to $82.52 \%$ for the finger flexor muscles of the right (dominant) hand. On a general level girls on average achieved 71.55\% of basic explosiveness in realtion to boys (Graph 1). These results are very similar to the results of previously published research that dealt with inter gender power differences of different muscle groups (Chen et al., 2012), where it has been found that girls at the general level account for $37-68 \%$ of the muscle power achieved by men, with lower results achieved for all of the tested muscle groups. In the context of the results obtained by this study, it is important to point out the fact that smaller inter gender differences in exerted power have been found in the extensor muscle groups of the lower extremities, where girls achieve results at the level of $65 \%$ of the value of the results achieved by men (Chen et al., 2012) which, although concerning different properties, somewhat correlates with the findings of our study.

However, when the results are considered from the aspect of values partialized relative to the skeletal muscle mass (SMM), the observed differences between the tested boys and girls are drastically reduced, indicating a relatively equal contractile potential in the function of pure muscle mass, regardless of the gender of the participants. In this respect, the absolute values total IPD of $71.55 \%$ (IPD RFDF ALL), and relative IPD value of $101.98 \%$ (IPD RFDF$\mathrm{ALL}_{\mathrm{SMM}}$ ) can be indicative (Graph 2). This can be explained by the higher percentage of muscle mass in the body composition of boys (PSMM\% $=54.66 \pm 1.42$ ) compared to girls $(\mathrm{PSMM} \%=49.99 \pm 3.81)$, and by the fact that girls have lower total body mass, and hence, lower absolute muscle mass. Also, these results correlate with the previously determined fact that men and women have relatively small differences in RFD in conditions of maximal voluntary contraction (KentBraun \& Alexander, 1999), i.e. explosive isometric muscle force exerted without involving the external muscle electro stimulation in terms of increasing the level of achieved activation.

It is necessary to considering that even with relative indicators of the basic explosive isometric muscle force of the ankle joint extensor muscles (plantar flexors), it has been established that the IPD is at the level of $133.82 \%$, indicating that the tested girls on average achieved $1 / 3$ better results than boys in the given test.

Also, one of the possible explanations for the determined differences in the parameters of basic and specific explosive isometric muscle force, regardless of the muscle group observed, relates to the previ- 
ously established differences in the percentage of different type muscle fibers and the differences in the overlapping area of myofilaments in muscle fibers in favor of men (Staron et al., 2000; Kent-Braun \& Alexander, 1999), which could have caused an absolute higher potential for expressing explosiveness in boys. Second potential cause of the inter gender differences can be the established difference in the distribution of contractile tissue between the upper and lower part of the body. A higher percentage share of contractile tissue in the lower part of the body in women (Janssen et al., 2000) was determined, but also a higher percentage of muscle mass in the male body composition and an absolute higher skeletal muscle mass in boys.

Possible reason for the determined values of the specific explosive isometric muscle force of the fingers flexor muscles of the left and right hand, both from the aspect of absolute and relative values, in addition to the greater distribution of muscle mass in the cranial part of the body in men (Janssen et al., 2000 ), most likely indicate the presence of a specific adaptation as a consequence of judo training, given the fact that the absolute values of $\mathrm{RFD}_{\text {max }}$ at the level of $4623.1 \mathrm{~N} / \mathrm{s}^{-1}$ for both left and right hand have been found. The average absolute values of specific explosive isometric muscle force at the level of $5197.6 \mathrm{~N} / \mathrm{s}^{-1}$ and $4040.4 \mathrm{~N} / \mathrm{s}^{-1}$ for both hands have been determined by previous study which examined adult trained wrestlers and moderately active subjects (Marković et al., 2016). Based on the comparison of the previous results with the results of this research, it can be argued that cadet judo athletes on the handgrip test achieve results at the level of $88.94 \%$ compared to adult wrestlers and $114.42 \%$ compared to adult moderately active participants. This can be interpreted as the direct influence of judo training.

\section{CONCLUSION}

The aim of this paper is to define descriptive characteristics as well as the parameters of the difference in explosive isometric muscle force in systemically trained and selected cadet age judo athletes, both from the aspect of the absolute values and from the aspect of the values partialized relative to the skeletal muscle mass (SMM). The basic method used in this research was the laboratory testing method using tensiometric probes. The research sample in this study consisted of 14 cadet age judo athletes, of which 10 boys and 4 girls. Explosive isometric muscle force was analyzed in relation to its basic $\left(\mathrm{RFDF}_{\max }\right)$ and specific $\left(\mathrm{RFD}_{\max }\right)$ dimension, while the following five muscle groups were tested: flexor muscles of the left (ŠL) and the right hand (ŠD), back (MRT) and leg extensor muscles (NOGE) and the ankle joint plantar flexor muscles (LIST).

On the basis of the obtained results, it can be argued that a general, statistically significant, difference exists in the tested cadet age judo athletes in the function of gender, both considering the absolute values of the variables of general and specific explosive isometric muscle force (Wilks' Lambda Value 0.000, F = 898.61, $\mathrm{p}=0.000$ ), as well as between the partialized (relative) values of basic and specific explosive isometric muscle force (Wilks' Lambda Value 0.001, F = $325.71, \mathrm{p}=0.000)$.

The highest level of inter gender difference considering the absolute values of the measured explosiveness was determined for the variables of the specific explosive isometric muscle force for the left hand $\left(\mathrm{RFD}_{\max } \check{S}_{\mathrm{S}} \mathrm{L}, \mathrm{p}=0.001, \mathrm{Eta}^{2}=0.618\right.$, i.e. $61.8 \%$ ), followed by leg extensor muscles $\left(\mathrm{RFD}_{\max } \mathrm{NOGE}\right.$, $\mathrm{p}=0.003$, $\mathrm{Eta}^{2}=0.527$, i.e. $\left.52.7 \%\right)$ and the right hand flexor muscles $\left(\mathrm{RFD}_{\max } \mathrm{S} \mathrm{D}, \mathrm{p}=0.005, \mathrm{Eta}^{2}=0.493\right.$, i.e. $49.7 \%)$. Considering the values of the variables partialized in relation to skeletal muscle mass (SMM), the highest level of difference was determined for variables of specific explosive isometric muscle force of the left hand $\left(\mathrm{RFD}_{\max } \check{\mathrm{S}}_{\mathrm{S}} \mathrm{SMM}_{\mathrm{M}}, \mathrm{p}=0.000, \mathrm{Eta}^{2}=0.657\right.$, i.e. $65.7 \%)$, right hand $\left(\mathrm{RFD}_{\max } \mathrm{S}_{\text {SMM }}, \mathrm{p}=0.003\right.$, $\operatorname{Eta}^{2}=0.523$, i.e.. 52.3\%) and the leg extensor muscles $\left(\mathrm{RFD}_{\max }-\mathrm{NOGE}_{\mathrm{SMM}}, \mathrm{p}=0.022, \mathrm{Eta}^{2}=0.367\right.$, i.e. $36.7 \%)$.

The total value of the gender dimorphism index (IPD) for absolute basic $\left(\mathrm{RFDF}_{\max }\right.$ ) and specific (RFD$\left.{ }_{\max }\right)$ explosive isometric muscle force was at the level of 71.55 and $53.09 \%$, respectively, which means that the tested girls reached $71.55 \%$ and $53.09 \%$ of the given contractile characteristic relative to the tested boys. However, when the measured variables are partialized relative to the SMM, the differences in the function of the gender are reduced to 101.98 and $71.58 \%$.

These results have shown that there are methodological indications of scientific justification in relation to the partialization of the results of explosive isometric muscle force, as a measure of development of the contractile muscle potential responsible 
for the most intensive expression of muscle force in the unit of time, in relation to skeletal muscle mass i.e. the mass of pure contractile tissue in the organism. In this way, the level of sensitivity of the variable itself is increased in terms of determining the real functional differences between the genders. The assumption is that this method of partialization of the results could be more sensitive in relation to determining the differences in contractile abilities and in relation to other criteria such as age, competitive efficiency, training period, etc.

Generally speaking, the results of this research present the initial quantitative values of the measured contractile characteristics, which can serve as initial standards in the function of evaluation and in function of defining qualitative assessments for assessing the level of fitness of athletes, which will increase the knowledge base in the system of preparation of young judo athletes, i.e. it will contribute the improvement of the existing technology of sports preparation in judo sport.

\section{REFERENCES}

1. Chen. G., Liu, L., Yu J. (2012). A comparative study on strength between american college male and female students in caucasian and asian populations. Sport science review 21(3-4), 153-165.

2. Detanico, D., Budal Arins, F., Dal Pupo, J., \& Dos Santos, S. G. (2012). Strength parameters in judo athletes: an approach using hand dominance and weight categories. Human Movement, 13(4), 330-336.

3. Dopsaj, M. (2015). Analitika i dijagnostika u sportu i fizičkom vaspitanju. [Analytics and Diagnostics in Sports and Physical Education. In Serbian]. (CD-ROM). Fakultet sporta i fizičkog vaspitanja, Beograd.

4. Dopsaj, M., Ilić, V., Đorđević-Nikić, M., Vučković, M., Eminović, F., Macura, M., \& Ilić, D. (2015). Descriptive model and gender dimorphism of body structure of physically active students of Belgrade University: Pilot study. Anthropologist, 19(1), 239-248.

5. Dopsaj, M., Koropanovski, N., Vučković, G., Blagojević, M., Marinković, B., \& Miljuš, D. (2007). Maximal isometric hand grip force in well-trained university students in Serbia: De-

\section{Limitations}

This study was conducted on a relatively small sample of participants consisting of 10 male and 4 female judo athletes who were all members of the cadet selection of the same judo team. This somewhat diminishes the possibility of generalization of the findings and points to the need for further systematic investigation of the characteristics of explosive isometric muscle force, and muscle force in general, with the inclusion of a larger number of subjects in the sample.

\section{Acknowlegements}

The paper is a part of the project "Effects of the Applied Physical Activity on Locomotor, Metabolic, Psychosocial and Educational Status of the Population of the Republic of Serbia", number III47015, funded by the Ministry of Education, Science and Technological Development of the Republic of Serbia - Scientific Projects 2011 - 2018 Cycle.

scriptive, functional and sexual dimorphic model. Serbian Journal of Sports Sciences, 1(4), 138-147.

6. Dopsaj, M., Milošević, M., Blagojević, M. (2000). Analysis of the reliability and factoral validity of selected muscle force mechanical characteristics during isometric multi joint test. U Y. Hong, D.P. Johns (ur.), Proceedings of XVIII international simposium on biomechanics in sport, (str. 146149). Hong Kong: Department of sports science and physical education - The Chinese University of Hong Kong.

7. Dopsaj, M., Milošević, M., Vučković, G., Blagojević, M. (2001) Metrological values of the test to assess mechanical characteristics of maximal isometric voluntary knee extensors muscle force from standing position. NBP-Nauka Bezbednost Policija, 6(2), 119-132.

8. Dopsaj, M., Thanopoulos, V., Race, V., Okičić, T. (2004). The relationship between competitive fitness levels in top sprinters swimmers at 50 and $100 \mathrm{~m}$ freestyle and indicators of explosiveness of different muscle groups: A result prediction model. $4^{\text {th }}$ International Conference on Strength Training: Book of Abstracts, Edited by: Kellis, E., 
Amiridis, I. and Vrabas., I., Aristotle University of Thessaloniki, Department of Physical Education and Sport Science at Serres, Serres, Greece, pp. $153-154$.

9. Franchini, E., \& Sterkowicz, S. (2000). Techniques used by judoists during the World and Olympic tournaments 1995-1999. Human Movement, 2(2), 23-33.

10. Franchini, E., Del Vecchio, F. B., Matsushigue, K. A., \& Artioli, G. G. (2011). Physiological profiles of elite judo athletes. Sports Medicine, 41(2), 147-166.

11. Franchini, E., Nunes, A. V., Moraes, J. M., \& Del Vecchio, F. B. (2007). Physical fitness and anthropometrical profile of the Brazilian male judo team. Journal of Physiological Anthropology, 26(2), 59-67.

12. Ilić, V., Mudrić, M., Kasum, G., Ćirković, M., Gavrilović, D. (2012). Morphological and motor characteristics of young judokas. Fizička Kultura, 66(2), 110-118.

13. Janssen, I., Heymsfield, S. B., Wang, Z., \& Ross, R. (2000). Skeletal muscle mass and distribution in 468 men and women aged 18-88 yr. Journal of Applied Physiology, 89(1), 81-88.

14. Kent-Braun, Jane A., \& Alexander V. Ng. (1999). Specific strength and voluntary muscle activation in young and elderly women and men. J. Appl. Physiol. 87(1): 22-29.

15. Koprivica, V. (2013). Teorija sportskog treninga. [Theory of sports training. In Serbian]. SIA: Beograd.
16. Marković, M., Dopsaj, M., Kasum, G. (2016). Differences between contractile characteristics of wrestler's hand and control group of young, moderately active people. U S. Pantelić (ur.), Fis communications book of proceedings, (str. 44-53). Niš: FSFV - Univerzitet u Nišu.

17. Monteiro, L. (2016). Analysis of rate force development, power and resistance explosive strength indicators in top elite vs. elite male judokas. U H. Sertić, S. Čorak i I. Segedi (ur.). Applicable Research in Judo Proceedings book, (str. 36-39). Poreč:Faculty of kinesiology - University of Zagreb.

18. Monteiro, L., Chambel, L., \& Cardoso, M. (2011). Elite and sub-elite judokas: the factors behind international success.U A.A. Figueiredo i C. Gutierrez-Garcia (ur.). Scientific congress on martial arts and combat sports, proceedings (str.73-76). Viseau:Instituto politecnico de Viseau.

19. Staron, R. S., Hagerman, F. C., Hikida, R. S., Murray, T. F., Hostler, D. P., Crill, M. T., \& Toma, K. (2000). Fiber type composition of the vastus lateralis muscle of young men and women. Journal of Histochemistry \& Cytochemistry, 48(5), 623-629.

20. Tanner, R., Gore, C. (2013). Physiological Tests for Elite Athletes (Sec. Ed.). Australian Institute of Sport. Champaign, IL: Human Kinetics, pp.212.

21. Thomas, S. G., Cox, M. H., LeGal, Y. M., Verde, T. J., \& Smith, H. K. (1989). Physiological profiles of the Canadian National Judo Team. Canadian Journal of Sport Sciences= Journal Canadien des Sciences du Sport, 14(3), 142-147. 


\title{
FUERZA (POTENCIA) EXPLOSIVA DE DISTINTOS GRUPOS MUSCULARES DE LOS JUDOCAS DE EDAD DE CADETE EN LA FUNCIÓN DEL SEXO
}

\begin{abstract}
Resumen
El objetivo del presente trabajo es establecer la diferencia entre la fuerza (potencia) explosiva en judocas varones y judocas hombres de la edad de cadete. Los resultados de las capacidades contráctiles medidas se obtuvieron aplicando las baterías de pruebas estándar, utilizando el método de dinamometría isométrica, para los cinco grupos musculares como sigue: el músculo flexor de dedos de las manos izquierda y derecha, el extensor de la musculatura dorsal-lumbar, el extensor de piernas y extensor de tobillo. La medición abarcó una muestra de 14 examinados y examinadas en total que compitieron en el sistema del campeonato nacional individual de la República de Serbia para la determinada edad. Sobre la base de los resultados obtenidos se puede afirmar que existe una diferencia general estadísticamente considerable de los judocas examinados en función del sexo, tanto entre los valores absolutos de las variables de fuerza (potencia) explosiva general y específica, en el nivel Wilks' Lambda Value 0.000, F=898.61, p=0.000, como también entre los valores parcializados (relativos) de las variables medidas en el nivel Wilks' Lambda Value 0.001, $\mathrm{F}=325.71, \mathrm{p}=0.000$. El mayor nivel de diferencia entre los sexos y en relación con los valores absolutos, se estableció en las variables de la fuerza (potencia) explosiva específica en la mano izquierda (RFDmax_MI, $\mathrm{p}=0.001$ ), para los músculos extensores de piernas (RFDmax_PIERNAS, $\mathrm{p}=0.003$ ), así como también para la mano derecha (RFDmax_MD, $\mathrm{p}=0.005)$. En relación con los valores parcializados de las variables sobre la base de la masa muscular de esqueleto (MME), el mayor nivel de diferencia se estableció en las variables de la fuerza (potencia) explosiva específica para las manos izquierda y derecha, respectivamente (RFDmax_MIMME, $\mathrm{p}=0.000$; RFDmax MDMME, $\mathrm{p}=0.003$ ). El valor sumado del índex de dimorfismo sexual (IDS) para la fuerza (potencia) explosiva absoluta general (RFDFmax) y específica (RFDmax) está en nivel de 71.55 y $53.09 \%$, lo que significa que las muchachas examinadas alcanzaron $71.55 \%$ y $53.09 \%$ de las características contráctiles dadas en relación con los muchachos examinados. Sin embargo, parcializando las variables medidas en relación con la MME, las diferencias mencionadas en función del sexo disminuyen al nivel de 101.98 y 71.58\%. Observando generalmente, los resultados obtenidos demostraron que existen las indicaciones metodológicas de justificación científica en relación con la parcialización de los resultados de la fuerza explosiva, como medida del desarrollo de la potencialidad muscular contráctil para la expresión más intensa de la potencia muscular por unidad de tiempo en relación con la masa muscular de esqueleto.
\end{abstract}

Palabras claves: JUDO/ CADETES / DINAMOMETRÍA ISOMÉTRICA / FUERZA (POTENCIA) EXPLOSIVA

Reacived: 04. 05. 2017. Accepted: 07. 12. 2017 


\title{
ЕКСПЛОЗИВНА ЈАЧИНА (СИЛА) РАЗЛИЧИТИХ МИШИЋНИХ ГРУПА ШУДИСТА КАДЕТСКОГ УЗРАСТА У ФУНКЦИЈИ ПОЛА
}

\author{
Стефан Марковић ${ }^{1}$, Миливој Допсај ${ }^{2}$, Стеван Јовановић ${ }^{3}$ Тијана Русовац ${ }^{1}$, Наташа Цветковски $^{1}$ \\ ${ }^{1}$ Универзитета у Београду, Факултет спорта и физичког васпитања, студент ДАС \\ ${ }^{2}$ Универзитета у Београду, Факултет спорта и физичког васпитања \\ ${ }^{3}$ Универзитет у Нишу, Факултет спорта и физичког васпитања
}

\begin{abstract}
Сажетак
Циљ овог рада је утврђивање разлика између опште и специфичне експлозивне јачине (силе) код џудиста и џудисткиња кадетског узраста. Резултати мерених контрактилних способности су добијени применом стандардизоване батерије тестова, уз коришћење методе изометријске динамометрије, за пет мишићних група и то: мишића прегибача прстију леве и десне шаке, опружача леђно-слабинске мускулатуре, опружача ногу и опружача скочног зглоба. Мерење је обухватило узорак од укупно 14 испитаника и испитаница који су се такмичили у систему појединачног националног првенства Републике Србије за одговарајући узраст. На основу добијених резултата се може тврдити да постоји генерална статистички значајна разлика тестираних џудиста у функцији пола и то, како између апсолутних вредности варијабли опште и специфичне експлозиве јачине (силе), на нивоу Wilks' Lambda Value 0.000, F=898.61, p=0.000, тако и између парцијализованих (релативних) вредности мерених варијабли на нивоу Wilks' Lambda Value 0.001, F=325.71, p=0.000. Највећи ниво разлике између пола, а у односу на апсолутне вредности, је утврђен код варијабли специфичне експлозивне јачине (силе) и то за леву шаку (RFD_ ̌̌s, $\mathrm{p}=0.001)$, за мишиће опружаче ногу (RFD _NOGE, $\mathrm{p}=0.003$ ), те за десну шаку (RFD $\mathrm{p}=0.005)$. У односу на парцијализоване вредности варијабли на основу скелетне мишићне масе (SMM), највећи ниво разлике је утврђен код варијабли специфичне експлозивне јачине (силе) и то за леву и десну шаку, респективно (RFD $\left.{ }_{\max } \check{S}_{\mathrm{SMM}}, \mathrm{p}=0.000 ; \mathrm{RFD}_{\max } \check{S}_{\mathrm{SMM}}, \mathrm{p}=0.003\right)$. Сумарна вредност индекса полног диморфизма (IPD) ca за апсолутну општу ( $\mathrm{RFDF}_{\max }$ ) и специфичну $\left(\mathrm{RFD}_{\max }\right.$ ) експлозивну јачину (силу) налази на нивоу од 71.55 и $53.09 \%$, што значи да су тестиране девојчице достигле $71.55 \%$ и 53.09\% датих контрактилних карактеристика у односу на тестиране дечаке. Међутим, када се мерене варијабле парцијализују у односу на SMM, поменуте разлике у финкцији пола се смањују на ниво од 101.98 и 71.58\%. Генерално посматрано, добијени резултати су показали да постоје методолошке индиције научне оправданости у односу на парцијализацију резултата експлозивне јачине, као мере развијености контрактилног мишићног потенцијала за што интензивније испољавање мишићне силе у јединици времена, у односу на скелетну мишићну масу.
\end{abstract}

КљУчне речи: ЏУДО/ КАДЕТИ/ ИЗОМЕТРИЈСКА ДИНАМОМЕТРИЈА/ ЕКСПЛОЗИВНА ЈАЧИНА (СИЛА)

\section{УВОД}

Џудо је олимпијски борилачки спорт у коме је успешност одређена оптималном интеграцијом различитих компоненти припреме спортисте које се обједињено испољавају у променљивим условима такмичења. Може се описати као спорт високог интензитета, у коме спортиста покушава да баци или обори противника на леђа или да га контролише током борбе у партеру (Franchini et al., 2007). Према важећим џудо правилима, разликујемо више узрасних категорија где се у систему дугорочног развоја спортисте, и у систему селекције перспективних спортиста, по свом значају издвајају кадетска и јуниорска узрасна категорија, док је значај сениорске категорије пре свега у афирмисању максимално могућих такмичарских способности кроз постизање резултата на такмичењима од међународног значаја. Унутар сваке узрасне категорије, такмичари су даље подељени 
према јасно дефинисаним тежинским категоријама, што је уобичајено у борилачким спортским дисциплинама. У оквирима укупног развоја својих такмичарских способности, да би били успешни на интернационалним такмичењима, џудисти током тренинга морају постићи изузетан ниво физичке припремљености (Franchini et al., 2011) где ce, са физиолошког становишта, анаеробна моћ и капацитет, аеробна моћ и мишићна сила/снага сматрају главним способностима које треба развијати код џудо такмичара (Thomas et al., 1989), па су ове карактеристике и биле у фокусу досадашњих истраживања.

Анализа борбе у џудоу указује и на разлике у испољавању силе и снаге међу џудистима различитих категорија (Franchini \& Sterkowicz, 2000). Ова специфичност даље утиче на тактичку поставку борбе, те на доминантност употребе појединих техника или група техника, условно специфичних за сваку тежинску категорију. Ипак, непобитна је чињеница да оптималан ниво развоја димензија мишићне јачине (силе), у великој мери опредељује успешност на такмичењу, при чему се као један од значајних фактора и предиктора успешности издвају вредности експлозивне јачине (RFD - rate of force development) (Monteiro, 2016; Monteiro et al., 2011).

Иако су се у фокусу већег броја радова у вези са проблематиком физичких способности релевантних за успешност у џудоу нашли модалитети снаге и максимална јачина релевантних мишићних група (Detanico et al., 2012; Franchini et al., 2011), постоји недостатак доступних података у смислу опште и специфичне експлозивне јачине (силе), независно од посматране узрасне категорије. С обзиром на чињеницу да спортска каријера представља вишегодишњи процес усмерен ка постизању максималних резултата, у оквиру кога се могу разликовати три стадијума са припадајућим етапама (Koprivica, 2013), те да се кадетски узраст недвосмислено подудара са првим стадијумом развоја спортске каријере - стадијумом ठазичне припреме, намеће се закључак да је у овом узрасту неопходно обезбедити услове за неометан и вишестран развој психофизичког потенцијала спортисте, као предуслова за каснију специјализацију. Кадетски узраст је такође карактеристичан због феномена убрзаног биолошког развоја који због специфичности раста сваког појединца условљава појаву хетерохроности биолошког развоја уопште, као и хетерохроности развоја различитих способности, посматрано и са аспекта узраста и са аспекта пола. У модерном концепту технологије развоја врхунског спортисте, паралелно са током процеса селекције треба да отпочне и тече процес тестирања и евалуације добијених резултата у односу на стандарде утврђене за сваки појединачни узраст и такмичарски ниво (Koprivica, 2013; Dopsaj, 2015). Ипак, неопходно је истаћи чињеницу да је позитиван утицај систематског тренинга у џудо спорту на морфолошке карактеристике и моторичке способности укључене деце документован и на млађим узрасним категоријама (Ilić et al., 2012), па се и раније укључивање деце у систематско бављење џудо спортом у том смислу може сматрати оправданим и пожељним.

У складу са претходним, овој рад представља једно од иницијалних квантитативних истраживања чији је циљ дефинисање дескриптивних карактеристика, као и параметара разлика експлозивне јачине (силе) код системски тренираних и селектираних џудиста кадетске узрасне категорије и то, како са аспекта апсолутних, тако и са аспекта вредности парцијализованих у односу на масу скелетних мишића (SMM). Релативизација у односу на SMM је омогућена применом нове методологије мерења телесне структуре испитаника, односно коришћењем система "InBody 720" чији се рад заснива на мерном принципу мултиканалне мултисегменталне биоелектричне импеданце (Dopsaj et al., 2015).Секундарни циљ овог истраживања сагледава се у добијању иницијалних вредности мерених контрактилних карактеристика, који могу послужити као почетни стандарди у функцији евалуације и дефинисању квалитативних оцена датог нивоа припремљености тестираних спортиста, што ће све сумарно утицати на повећање фундуса знања у систему припреме младих џудиста, односно усавршиће постојећу технологију спортске припреме џудо спорта.

\section{МЕТОД РАДА}

Основни метод рада примењен у овом истраживању је анализа заснована на лабораторијским мерењима респективних параметара. Узорковање података за анализу је обављено динамометријом- применом тензиометријских сонди. 


\section{Узорк испитаника}

Узорак испитаника у овом истраживању се састојао од 14 такмичара кадетске категорије у џудо спорту, и то 10 мушкараца и 4 девојке. Основне дескриптивне карактеристике узорка су приказане у Табели 1.

Табела 1. Основне дескриптивне карактеристике узорка

\begin{tabular}{|c|c|c|}
\hline Варијабле & Кадети & Кадеткиње \\
\hline Узраст (год.) & $15.5 \pm 0.7$ & $16.4 \pm 0.1$ \\
\hline ТВ (цм) & $174.6 \pm 4.6$ & $159.7 \pm 7.8$ \\
\hline TM (кг) & $65.9 \pm 7.0$ & $55.7 \pm 11.9$ \\
\hline $\mathrm{BMI}\left(\mathrm{\kappa} \cdot \mathrm{m}^{-2}\right)$ & $21.68 \pm 2.70$ & $21.7 \pm 3.56$ \\
\hline $\mathrm{PBF}(\%)$ & $3.32 \pm 0.92$ & $11.14 \pm 7.55$ \\
\hline $\operatorname{PSMM}(\%)$ & $54.66 \pm 1.42$ & $49.99 \pm 3.81$ \\
\hline Тренажни стаж (год.) & $3.9 \pm 2.7$ & $3.17 \pm 0.62$ \\
\hline Недељни број тренинга & $4.0 \pm 0.5$ & $4.0 \pm 0.5$ \\
\hline Обим недељног тренажног рада (мин.) & $420 \pm 30$ & $420 \pm 30$ \\
\hline
\end{tabular}

Сви испитаници су били чланови Џудо клуба "Винча" и такмичили су се у систему појединачног националног такмичарског првенства дате узрасне категорије у Републици Србији. Од укупног узорка, два такмичара су била чланови националне репрезентативне селекције.

\section{Поступак мерења}

Мерење параметара мишићне јачине (силе) извршено је методом изометријске тензиометриje, помоћу тензиометријских сонди (Isometrics SMS All4Gym, Београд). Сва мерења су обављена на Факултету спорта и физичког васпитања Универзитета у Београду, у Методичко-истраживачкој лабораторији (МИЛ). Мерења су реализована у јутарњим часовима у периоду од 09:00 до 11:30, применом стандардизованог поступка тестирања и примењених тестова (Dopsaj et al., 2000; Dopsaj

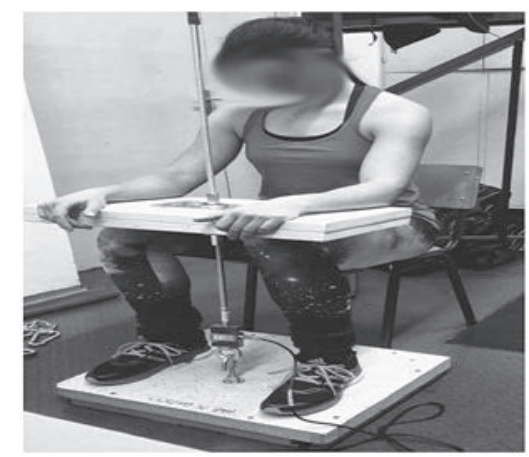

Слика 1. Тест плантарна флексија седећи et al., 2001; Dopsaj et al., 2004; Dopsaj et al., 2007).

Процедура мерења је подразумевала да су сви испитаници прво «загревали» и «истезали» самосталним избором вежби у трајању од 10 минута. После тога се приступило мерењу и то по следећој процедури: испитаницима је објашњена и приказана процедура мерења, након чега је сваки испитаник имао по два пробна покушаја и то средњим и високим интензитетом ради специфичног загревања и упознавања са процедуром мерења. Након одмора од 5 минута приступило се мерењима. Мерење је реализовано методом тест-ретест, односно сви испитаници су мерени два пута, где је пауза између покушаја трајала 3 минута (Tanner \& Gore, 2013). За даљу статистичку анализу је узиман бољи резултат. На Сликама 1 - 4 су приказане процедуре мерења за примењену батерију тестова.

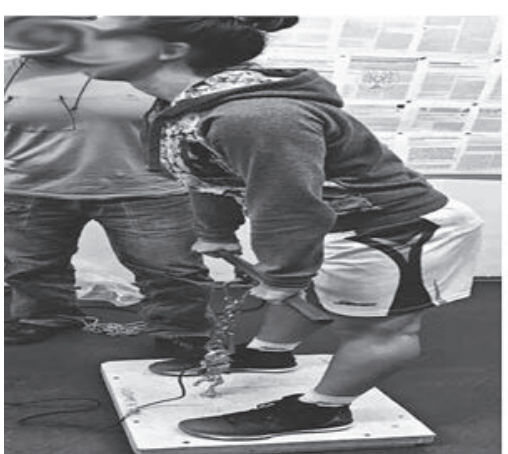

Слика 2. Тест мртво вучење 


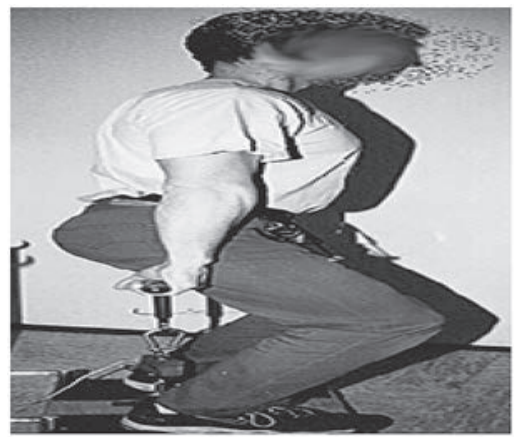

Слика 3. Тест опружање ногу

\section{Варијабле}

За потребе овог истраживања испитиване су карактеристике јачине тј. контрактилне карактеристике мишића мерене у изометријским условима испољавања, са аспекта интензитета њеног испољавања. Другим речима, испитиване су карактеристике експлозивне јачине тј. експлозивне мишићне силе. Експлозивна јачина је анализирана у односу на општу $\left(\mathrm{RFDF}_{\max }\right)$ и специфичну $\left(\mathrm{RFD}_{\max }\right)$ вредност. Сва тестирања су реализована на следећим мишићним групама: прегибачи прстију леве (ŠL) и десне шаке (ŠD), опружачи леђно-слабинске мускулатуре (MRT), опружачи ногу (NOGE) и опружачи скочног зглоба (плантарни флексори, LIST), и то применом следећих варијабли:

Варијабле за процену опште експлозивне јачине биле су:

- RFDF $_{\max }$ ŠL, општа експлозивна јачина мишића прегибача прстију леве шаке, изражена у N/s;

- $\mathrm{RFDF}_{\text {max }}$ ŠD, општа експлозивна јачина мишића прегибача прстију десне шаке, изражена у N/s;

- RFDF $_{\text {max }}$ MRT, општа експлозивна јачина мишића опружача леђно-слабинске мускулатуре, изражена у N/s;

- $\mathrm{RFDF}_{\text {max }}$ NOGE, општа експлозивна јачина опружача ногу, изражена у N/s;

- RFDF ${ }_{\text {max }}$ LIST, општа експлозивна јачина опружача скочног зглоба (плантарних флексора), изражена у N/s.

Варијабле за процену специфичне експлозивне јачине биле су:

- $\mathrm{RFD}_{\max }$ ŠL, специфична експлозивна јачина мишића прегибача прстију леве шаке, изражена у N/s;

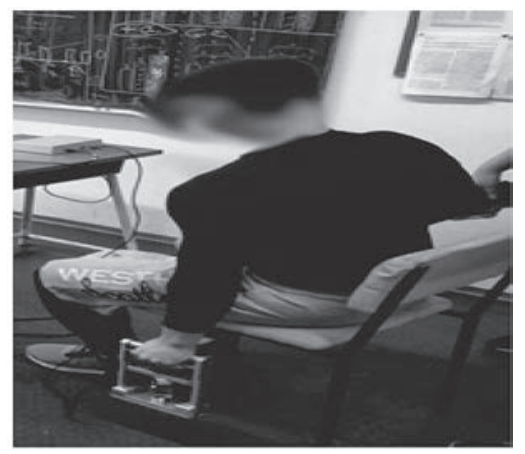

Слика 4. Тест стисак шаке

- $\mathrm{RFD}_{\text {max }}$ ŠD, специфична експлозивна јачина мишића прегибача прстију десне шаке, изражена у N/s;

- $\mathrm{RFD}_{\text {max }}$ MRT, специфична експлозивна јачина мишића опружача леђно-слабинске мускулатуре, изражена у N/s;

- $\mathrm{RFD}_{\max } \mathrm{NOGE}$, специфична експлозивна јачина опружача ногу, изражена у N/s;

- RFD ${ }_{\text {max }}$ LIST, специфична експлозивна јачина опружача скочног зглоба (плантарних флексора), изражена у N/s.

Такође, све апсолутне вредности испитиваних варијабли су нормализоване у односу на чисту мишићну масу (SMM - Skeletal Muscle Mass) ради добијања карактеристичних података и у односу на поменуту димензију телесног састава директно одговорну за испољавање контрактилног потенцијала организма.

Све варијабле су нормализоване применом стандардног обрасца израчунавања, као што је дато формулом: $\mathrm{RFDF}_{\max } \mathrm{X}_{\mathrm{SM}}=\mathrm{RFDF}_{\max } \mathrm{X} / \mathrm{SMM}$, где je $\mathrm{RFDF}_{\max } \mathrm{X}$ - измерена вредност дате димензије експлозивне јачине за дату мишићну групу, SMM - вредност масе скелетних мишића, изражена у кг.

Резултати експлозивности, и апсолутне и парцијализоване вредности, приказани су и у функцији пола, односно приказани су у смислу полног диморфизма, где је индекс полног диморфизма (IPD) израчунат као количник датог резултата девојчица у односу на дати резултат дечака, помножен са 100 (Dopsaj et al., 2015).

\section{Статистичка обрада и анализа података}

Сви добијени подаци мерених варијабли су у првом кораку анализе обрађени применом методе дескриптивне статистике ради израчунавања основне мере централне тенденције - средње вредности (АС - аритметилчка средина), мера 
дисперзије - стандардна девијација (SD), коефицијента варијације (cV\%), као и мере распона резултата - минимална (Min) и максимална (Max) вредност измерених варијабли. За потребе утврђивања разлика између испитиваних варијабли, а у функцији полова, коришћене су методе мултиваријантне (MANOVA) и униваријантне (ANOVA) статистичке анализе. Све анализе су реализоване применом софтверских пакета Microsoft Office Excel 2007 i IBM SPSS Statistics v23.0, док је ниво статистичке значајности био дефинисан на основу критеријума $95.0 \%$ вероватноће, за вредност $\mathrm{p} \leq 0.05$.

\section{РЕЗУЛТАТИ}

У Табели 2 су садржани показатељи дескриптивне статистике у односу на испитиване варијабле према полу испитаника.

Табела 2. Основни дескриптивни показатељи испитиваног узорка у односу на пол

\begin{tabular}{|c|c|c|c|c|c|c|c|c|c|c|}
\hline \multirow[b]{2}{*}{ Варијабле } & \multicolumn{5}{|c|}{ Дечаци } & \multicolumn{5}{|c|}{ Девојчице } \\
\hline & Mean & SD & $\mathrm{cV} \%$ & Min & Max & Mean & SD & $\mathrm{cV} \%$ & Min & Max \\
\hline $\mathrm{RFD}_{\max } \check{S}^{\mathrm{S} L}(\mathrm{~N} / \mathrm{s})$ & 2253.9 & 558.50 & 2.48 & 1776 & 3298 & 990.67 & 51.16 & 5.16 & 953 & 1063 \\
\hline $\mathrm{RFDF}_{\max } \check{\mathrm{S} L}(\mathrm{~N} / \mathrm{s})$ & 425.7 & 186.21 & 4.37 & 246.80 & 832.28 & 272.69 & 134.11 & 49.18 & 136.17 & 454.98 \\
\hline $\mathrm{RFD}_{\max } \check{\mathrm{SD}}(\mathrm{N} / \mathrm{s})$ & 2369.2 & 679.56 & 2.87 & 1779 & 3999 & 1177.33 & 69.21 & 5.88 & 1123 & 1275 \\
\hline $\mathrm{RFDF}_{\max }=\check{S} \mathrm{D}(\mathrm{N} / \mathrm{s})$ & 458.5 & 172.20 & 3.76 & 232.5 & 807.69 & 378.34 & 180.21 & 47.63 & 212.85 & 628.93 \\
\hline $\mathrm{RFD}_{\max } \mathrm{MRT}(\mathrm{N} / \mathrm{s})$ & 6231.0 & 3036.07 & 4.87 & 3673 & 13679 & 3322.33 & 386.92 & 11.65 & 2829 & 3774 \\
\hline $\mathrm{RFDF}_{\max } \mathrm{MRT}(\mathrm{N} / \mathrm{s})$ & 935.5 & 292.12 & 3.12 & 554.70 & 1364.71 & 585.78 & 162.61 & 27.76 & 446.13 & 813.83 \\
\hline $\mathrm{RFD}_{\max } \mathrm{NOGE}(\mathrm{N} / \mathrm{s})$ & 4919.67 & 1390.14 & 2.83 & 3329 & 7425 & 2298 & 272.99 & 11.88 & 1999 & 2659 \\
\hline $\mathrm{RFDF}_{\max } \mathrm{NOGE}(\mathrm{N} / \mathrm{s})$ & 1059.57 & 550.35 & 5.19 & 466.4 & 2183.98 & 724.21 & 43.81 & 6.05 & 668.75 & 775.86 \\
\hline $\mathrm{RFD}_{\max } \mathrm{LIST}(\mathrm{N} / \mathrm{s})$ & 12314.4 & 1821.38 & 1.48 & 9819 & 15997 & 8840.33 & 2627.62 & 29.72 & 5738 & 12163 \\
\hline $\mathrm{RFDF}_{\max } \mathrm{LIST}(\mathrm{N} / \mathrm{s})$ & 2839.53 & 890.41 & 3.14 & 1834.9 & 5048.1 & 2277.07 & 421.51 & 18.51 & 1856.82 & 2853.32 \\
\hline $\begin{array}{l}\mathrm{RFD}_{\max -\mathrm{S} L} \mathrm{~L}_{-\mathrm{SMM}} \\
\left(\mathrm{N} / \mathrm{s}^{1 \mathrm{kggSMM}}\right)\end{array}$ & 61.85 & 9.55 & 15.44 & 52.67 & 77.38 & 36.9 & 6.04 & 16.36 & 29.50 & 44.29 \\
\hline $\begin{array}{l}\operatorname{RFDF}_{\max -} \check{S L}_{\mathrm{SMM}} \\
\left(\mathrm{N} / \mathrm{s}^{-1 \mathrm{kgSMM}}\right)\end{array}$ & 11.60 & 4.47 & 38.5 & 7.03 & 22.02 & 10.65 & 6.16 & 57.9 & 4.22 & 18.96 \\
\hline $\begin{array}{l}\mathrm{RFD}_{\max } \check{\mathrm{S}}_{\mathrm{SMM}} \\
\left(\mathrm{N} / \mathrm{s}^{-1 \mathrm{kgSMM}}\right)\end{array}$ & 64.8 & 11.39 & 17.57 & 53.08 & 88.67 & 43.36 & 3.17 & 7.32 & 39.47 & 47.25 \\
\hline $\begin{array}{l}\operatorname{RFDF}_{\max } \check{S} \mathrm{D}_{\mathrm{SMM}} \\
\left(\mathrm{N} / \mathrm{s}^{-1 \mathrm{kgSMM}}\right)\end{array}$ & 12.73 & 4.60 & 36.15 & 6.62 & 21.89 & 13.22 & 4.53 & 34.28 & 8.87 & 19.47 \\
\hline $\begin{array}{l}\mathrm{RFD}_{\max } \mathrm{MRT}_{\mathrm{SMM}} \\
\left(\mathrm{N} / \mathrm{s}^{-1 \mathrm{kgSMMM}}\right)\end{array}$ & 167.75 & 60.73 & 36.2 & 97.17 & 303.30 & 124.91 & 28.66 & 22.94 & 87.59 & 157.25 \\
\hline $\begin{array}{l}\mathrm{RFDF}_{\max } \mathrm{MRT}_{\mathrm{SMM}} \\
\left(\mathrm{N} / \mathrm{s}^{-1 \mathrm{kgSMM}}\right)\end{array}$ & 25.93 & 7.78 & 30.01 & 16.71 & 40.81 & 22.31 & 8.49 & 38.07 & 13.81 & 33.91 \\
\hline $\begin{array}{l}\mathrm{RFD}_{\text {max }} \mathrm{NOGE}_{\mathrm{SMM}} \\
\left(\mathrm{N} / \mathrm{s}^{-1 \mathrm{kgSMM}}\right)\end{array}$ & 136.42 & 35.25 & 25.84 & 88.07 & 201.22 & 86.34 & 19.96 & 23.12 & 61.89 & 110.79 \\
\hline $\begin{array}{l}\mathrm{RFDF}_{\text {max }} \mathrm{NOGE}_{\mathrm{SMM}} \\
\left(\mathrm{N} / \mathrm{s}^{-1 \mathrm{kgSMM}}\right)\end{array}$ & 28.68 & 12.36 & 43.1 & 14.05 & 49.76 & 27.05 & 4.80 & 17.76 & 20.70 & 32.33 \\
\hline $\begin{array}{l}\mathrm{RFD}_{\text {max }} \mathrm{LIST}_{\text {SMM }} \\
\left(\mathrm{N} / \mathrm{s}^{-1 \mathrm{kgSMM}}\right)\end{array}$ & 341.04 & 25.51 & 7.48 & 295.66 & 375.81 & 319.09 & 69.34 & 21.73 & 221.54 & 376.56 \\
\hline $\begin{array}{l}\text { RFDF }{ }_{\max } \mathrm{LIST}_{\text {SMM }} \\
\left(\mathrm{N} / \mathrm{s}^{-1 \mathrm{kgSMM}}\right)\end{array}$ & 61.85 & 9.55 & 15.44 & 52.67 & 77.38 & 82.8 & 7.86 & 9.49 & 71.69 & 88.38 \\
\hline
\end{tabular}


У Табели 3 су приказани резултати анализа разлика између испитиваних група у функцији пола (MANOVA и ANOVA). На осовну приказаних резултата MANOVE може се тврдити да постоји статистички значајна разлика како између апсолутних вредности варијабли опште и специфичне експлозивне јачине (силе), на нивоу Wilks' Lambda Value $0.000, \mathrm{~F}=898.61, \mathrm{p}=0.000$, тако и између парцијализованих вредности опште и специфичне експлозивне јачине (силе), на нивоу Wilks' Lambda Value 0.001, F=325.71, p=0.000, тестираних џудиста кадетског узраста у функцији пола.

Највећи ниво разлике између полова, а у односу на апсолутне вредности, је утврђен код варијабли специфичне експлозивне јачине (силе) и то за леву шаку $\left(\mathrm{RFD}_{\max } \mathrm{S} \mathrm{L}, \mathrm{p}=0.001, \mathrm{Eta}^{2}=0.618\right.$, тj. 61.8\%), па затим за мишиће опружаче ногу (RFD ${ }_{\text {max }}$ NOGE, $\mathrm{p}=0.003, \mathrm{Eta}^{2}=0.527$, тj. 52.7\%), те за десну шаку $\left(\mathrm{RFD}_{\max } \check{\mathrm{S}} \mathrm{D}, \mathrm{p}=0.005, \mathrm{Eta}^{2}=0.493\right.$, тj. 49.7\%).

У односу на парцијализоване вредности варијабли на основу чисте мишићне масе, највећи ниво разлике је утврђен код варијабли специфичне експлозивне јачине (силе) и то за леву шаку $\left(\mathrm{RFD}_{\text {max }} \check{S}_{\text {SMM }}, \mathrm{p}=0.000, \mathrm{Eta}^{2}=0.657\right.$, тj. $\left.65.7 \%\right)$, за десну шаку ( $\mathrm{RFD}_{\max } \check{\mathrm{S}}_{\text {SMM }}, \mathrm{p}=0.003, \mathrm{Eta}^{2}=0.523$, тj. 52.3\%), и за мишиће опружаче ногу (RFD ${ }_{\max }$ $\mathrm{NOGE}_{\text {SMM }}, \mathrm{p}=0.022, \mathrm{Eta}^{2}=0.367$, тj. 36.7\%), док код осталих варијабли нису утврђене статистички значајне разлике.

Табела 3. Резултати MANOVA и ANOVE испитиваних варијабли у односу на пол

\begin{tabular}{|c|c|c|c|c|c|c|}
\hline \multicolumn{7}{|c|}{ MANOVA - multivariate test } \\
\hline & Ефекат & Value & $\mathrm{F}$ & $\mathrm{P}$ & Partial Eta ${ }^{2}$ & $\begin{array}{l}\text { Observed } \\
\text { Power }\end{array}$ \\
\hline Пол - апсолутне вредности & Wilks' Lambda & 0.000 & 898.61 & 0.000 & 1.000 & 1.000 \\
\hline $\begin{array}{c}\text { Пол - релативне вредности } \\
\text { (SMM) }\end{array}$ & Wilks' Lambda & 0.001 & 325.71 & 0.000 & 0.999 & 1.000 \\
\hline \multicolumn{7}{|c|}{ ANOVA - Test of Between - subjects Effects } \\
\hline & Varijabla & Mean Square & F value & $\mathrm{P}$ & Partial Eta ${ }^{2}$ & $\begin{array}{l}\text { Observed } \\
\text { Power }\end{array}$ \\
\hline \multirow{10}{*}{ Пол - апсолутне вредности } & $\mathrm{RFD}_{\max -} \check{\mathrm{S} L}$ & 4559229.6 & 19.44 & 0.001 & 0.618 & 0.981 \\
\hline & $\mathrm{RFDF}_{\max } \check{S}^{\mathrm{S} L}$ & 66886.0 & 2.19 & 0.164 & 0.154 & 0.276 \\
\hline & $\mathrm{RFD}_{\max -} \check{\mathrm{S}} \mathrm{D}$ & 4058854.6 & 11.68 & 0.005 & 0.493 & 0.880 \\
\hline & $\mathrm{RFDF}_{\max }-\check{S} \mathrm{D}$ & 18365.1 & 0.61 & 0.452 & 0.048 & 0.111 \\
\hline & $\mathrm{RFD}_{\max -\mathrm{MRT}}$ & 24172405.1 & 3.48 & 0.087 & 0.225 & 0.404 \\
\hline & $\mathrm{RFDF}_{\max } \_\mathrm{MRT}$ & 349422.4 & 4.95 & 0.046 & 0.292 & 0.534 \\
\hline & $\mathrm{RFD}_{\max -\mathrm{NOGE}}$ & 19637531.8 & 13.38 & 0.003 & 0.527 & 0.918 \\
\hline & $\mathrm{RFDF}_{\max }-\mathrm{NOGE}$ & 321320.5 & 1.41 & 0.258 & 0.105 & 0.195 \\
\hline & $\mathrm{RFD}_{\max -\mathrm{LIST}}$ & 34484137.2 & 8.18 & 0.014 & 0.405 & 0.747 \\
\hline & $\mathrm{RFDF}_{\max }-\mathrm{LIST}$ & 903885.1 & 1.41 & 0.257 & 0.105 & 0.195 \\
\hline \multirow{10}{*}{ Пол - релативне вредности } & $\mathrm{RFD}_{\max } \check{S} \mathrm{~L}_{\mathrm{SMM}}$ & 1778.5 & 22.95 & 0.000 & 0.657 & 0.992 \\
\hline & $\mathrm{RFDF}_{\max } \check{S}^{\mathrm{S}} \mathrm{L}_{\mathrm{SMM}}$ & 2.6 & 0.11 & 0.750 & 0.009 & 0.060 \\
\hline & $\mathrm{RFD}_{\max } \check{S}^{\mathrm{S}} \mathrm{D}_{\mathrm{SMM}}$ & 1313.8 & 13.17 & 0.003 & 0.523 & 0.914 \\
\hline & $\mathrm{RFDF}_{\max -} \mathrm{S}_{\mathrm{SMM}}$ & 0.7 & 0.03 & 0.858 & 0.003 & 0.053 \\
\hline & $\mathrm{RFD}_{\max }-\mathrm{MRT}_{\mathrm{SMM}}$ & 5244.4 & 1.77 & 0.209 & 0.128 & 0.232 \\
\hline & $\mathrm{RFDF}_{\text {max }} \mathrm{MRT}_{\mathrm{SMM}}$ & 37.4 & 0.59 & 0.457 & 0.047 & 0.109 \\
\hline & $\mathrm{RFD}_{\max -} \mathrm{NOGE}_{\mathrm{SMM}}$ & 7166.8 & 6.95 & 0.022 & 0.367 & 0.678 \\
\hline & $\mathrm{RFDF}_{\text {max }} \mathrm{NOGF}_{\mathrm{SMM}}$ & 7.6 & 0.06 & 0.806 & 0.005 & 0.056 \\
\hline & $\mathrm{RFD}_{\max -} \mathrm{LIST}_{\mathrm{SMM}}$ & 1376.9 & 0.82 & 0.384 & 0.064 & 0.132 \\
\hline & RFDF $_{\text {max }}$ LIST $_{\mathrm{SMM}}$ & 64.8 & 0.26 & 0.620 & 0.021 & 0.076 \\
\hline
\end{tabular}


На Графицима 1 и 2 су приказани резултати добијених вредности IPD у односу на апсолутне и парцијализоване (релативне) вредности мерене експлозивности (опште и специфичне) за примењене тестове. На основу добијених резултата ап- солутних вредности може се тврдити да је утврђена већа разлика специфичне експлозивности између полова (IPD RFD max $_{\text {- }} \mathrm{ALL}=53.09 \%$ ), у односу на ниво опште експлозивности (IPD RFDF ${ }_{\text {max }}$ ALL $=71.55 \%)$.

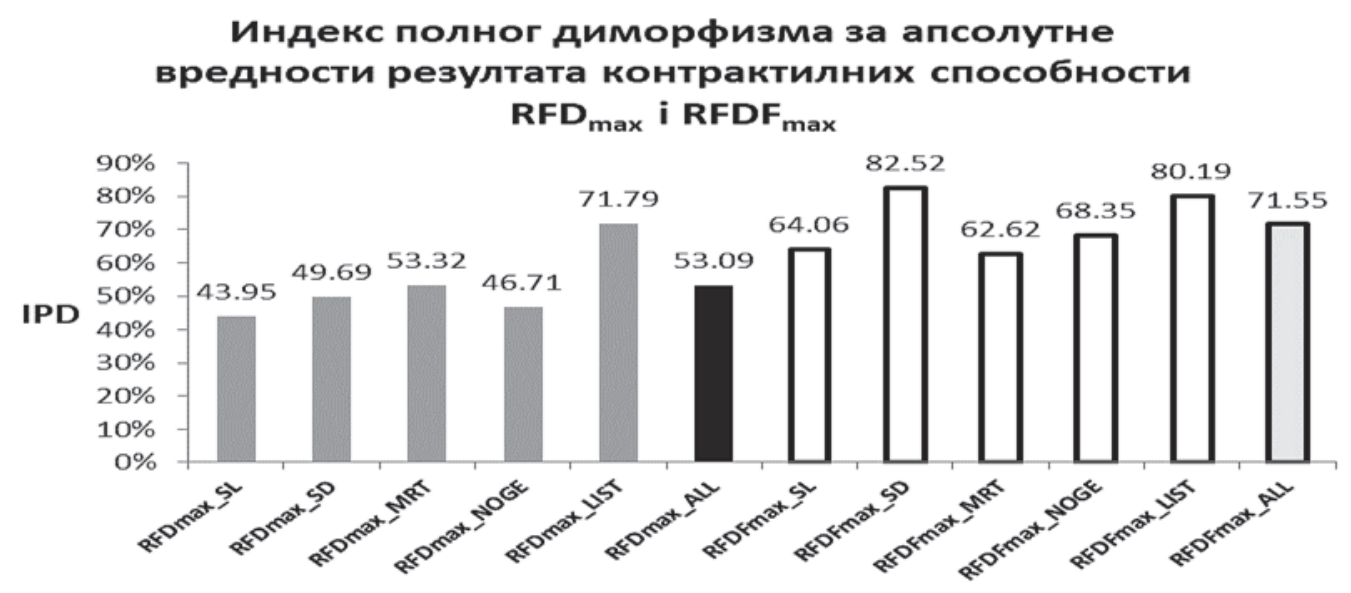

График 1. IPD у односу на апсолутне вредности варијабли експлозивне јачине (силе)

Као и у случају апсолутних вредности IPD (График 1), на основу добијених резултата парцијализованих (релативних) вредности експлозивне јачине (График 2), може се тврдити да је утврђена већа разлика специфичне експлозивности између полова (IPD RFD $\mathrm{max}_{\text {max }} \mathrm{ALL}_{\mathrm{SMM}}=71.58 \%$ ), у односу на ниво опште експлозивности (IPD RFD ${ }_{\text {Fmax }}{ } A L L_{\text {SMM }}$ $=101.98 \%)$.

\section{Индекс полног диморфизма за релативне вредности резултата контрактилних способности RFD $_{\text {max }}$ i RFDF $_{\text {max }}$}

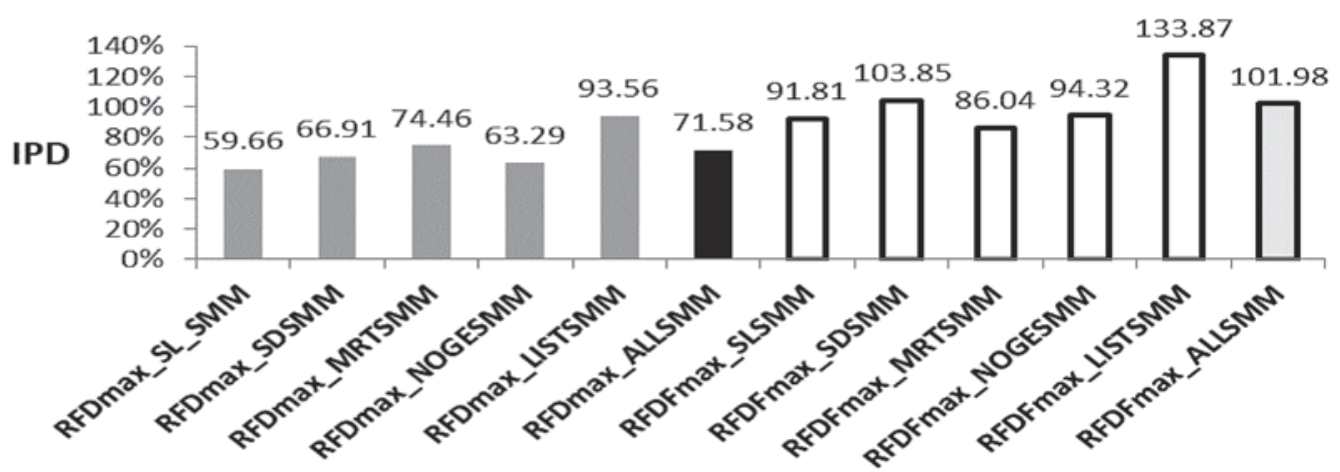

График 2. IPD у односу на парцијализоване (релативне) вредности варијабли експлозивне јачине (силе)

\section{ДИСКУСИЈА}

На основу резултата дескриптивне статистике може се закључити да се све измерене вредности испитиваних варијабли налазе у прихватљивом опсегу варијације резултата, јер се коефицијент варијације (cV\%) за дечаке налази код апсолут- них вредности у опсегу од $1.48 \%$ (RFD ${ }_{\max }$ LIST) до 5.19\% (RFDF ${ }_{\max } \_$NOGE), док су код девојчица у опсегу од $5.16 \%\left(\mathrm{RFD}_{\max }\right.$ ŠL $)$ до $49.18 \%\left(\mathrm{RFDF}_{\max }\right.$ ŠL) (Табела 1). У односу на парцијализоване вредности испитиваних варијабли може се закључити да се коефицијенти варијације, као мере хомогености резултата, код дечака налазе у распону 
од $7.48 \%\left(\mathrm{RFD}_{\max } \mathrm{LIST}_{\text {Sмм }}\right)$ до $43.1 \%\left(\mathrm{RFDF}_{\max }\right.$ $\mathrm{NOGE}_{\text {SMM }}$ ), док су код девојчица у опсегу од $7.32 \%$ $\left(\mathrm{RFD}_{\max } \check{S}_{\text {SMM }}\right)$ до $57.9 \%\left(\mathrm{RFDF}_{\max } \check{\mathrm{SL}}_{\mathrm{SMM}}\right)$. Како већина варијабли, односно $75.0 \%$ варијабли, имају изузетно низак ново варијације, тј. изузетно висок ниво хомогености (по 15 варијабли код оба пола имају варијацију испод $10 \%$, односно испод $30 \%$ ), док осталих $25.0 \%$ има вредност коефицијента варијације испод $60.0 \%$, на генералном нивоу се може закључити да су измерени резултати хомогени и репрезентативни у смислу валидне научне интерпретације.

У односу на достигнуте нивое развијености опште експлозивне јачине (силе), тј. варијабле $\mathrm{RFDF}_{\text {max }}$ за тест стисак шаке може се тврдити да је измерена максимална просечна вредност на нивоу од 425.70 и $458.51 \mathrm{~N} / \mathrm{s}$, за леву и десну шаку код дечака, односно 272.69 и $378.34 \mathrm{~N} / \mathrm{s}$ код девојчица, респективно (Табела 2). ANOVA је показала да у случају ових резултата није утврђена статистички значајна разлика између апсолутних карактеристика базичне експлозивности у односу на пол $\left(\right.$ Табела $3, \mathrm{RFDF}_{\text {max }} \mathrm{S}_{\mathrm{L}}-\mathrm{F}$ value $=2.19$, $\mathrm{p}=0.164 ; \mathrm{RFDF}_{\max } \check{S}^{\mathrm{S} D}-\mathrm{F}$ value $\left.=0.61, \mathrm{p}=0.452\right)$. Ако се добијена просечна вредност анализира у контексту полног диморфизма може се тврдити да се однос резултата девојчица и дечака код мерене варијабле за леву и десну шаку налази на нивоу од 64.05 и $82.52 \%$, респективно (Графикон 1), односно да је вредност индекса полног диморфизма (IPD) на просечном нивоу од $73.63 \%$. Другим речима, општи ниво експлозивности мишића прегибача прстију код девојчица се налази на око $3 / 4$ резултата дечака.

Код мишића опружача леђно-слабинске мускулатуре (тест мртво вучење), као једне од веома важних мишићних група са аспекта џудо спорта, измерена је просечна вредност $\mathrm{RFDF}_{\text {max }}$ од 935.49 $\mathrm{N} / \mathrm{s}$ код дечака и $585.78 \mathrm{~N} / \mathrm{s}$ код девојчица (Табела 2). Резултати ANOVE су показали да постоји статистички значајна разлика између поменутих апсолутних карактеристика експлозивности у односу на пол (Табела $3, \mathrm{RFDF}_{\text {max }} \mathrm{MRT}$ - $\mathrm{F}$ value $=4.95$, $\mathrm{p}=0.046)$. Девојчице су код датог теста оствариле мањи ниво опште експлозивности за чак 349.71 $\mathrm{N} / \mathrm{s}$, уз достигнути ниво IPD од 62.62\% (График 1). Другим речима, општи ниво експлозивности мишића опружача леђно-слабинске мускулатуре код девојчица се налази на око $2 / 3$ резултата дечака.
Просечна вредност опште експлозивне јачине за мишиће опружаче ногу била је на нивоу од $1059.57 \mathrm{~N} / \mathrm{s}$ код дечака и $724.21 \mathrm{~N} / \mathrm{s}$ код девојчица (Табела 2). Резултати ANOVE су показали да не постоји статистички значајна разлика између мерене експлозивности у односу на пол (Табела $3, \mathrm{RFDF}_{\text {max }}$ NOGE $-\mathrm{F}$ value $\left.=1.41, \mathrm{p}=0.258\right)$. Kao и у случају мишића леђно-слабинске мускулатуpe, и код мишића опружача ногу утврђено је да су девојчице оствариле мањи резултат за чак 335.36 $\mathrm{N} / \mathrm{s}$, уз достигнути ниво IPD од 68.35\% (График 1). За ову мишићну групу општа експлозивност мишића опружача ногу код девојчица се налазила на нивоу од око 2/3 у односу на дечаке.

Код мишића опружача скочног зглоба измерена је просечна вредност опште експлозивне јачине на нивоу од $2839.53 \mathrm{~N} / \mathrm{s}$ код дечака и 2277.07 N/s код девојчица (Табела 2). Резултати ANOVE су показали да не постоји статистички значајна разлика између поменутих апсолутних карактеристика експлозивности у односу на пол (Табела $3, \mathrm{RFDF}_{\max }$ LIST $-\mathrm{F}$ value $\left.=1.41, \mathrm{p}=0.257\right)$. И код мишића плантарних флексора је утврђено је да су девојчице оствариле мањи резултат за $562.46 \mathrm{~N} / \mathrm{s}$, уз достигнути ниво IPD од $80.19 \%$ (График 1). У случају ове мишићне групе резултат код девојчица се налази на нивоу од око 4/5 у односу на резултате утврђене код дечака.

У односу на достигнуте нивое развијености опште експлозивне јачине, али посматрано са аспекта парцијализованих вредности у односу на масу скелетних мишића, код теста стиска шаке измерени су резултати на нивоу од 11.60 и 12.73 $\mathrm{N} / \mathrm{s}^{-1 \mathrm{~kg} M м}$, код дечака и 10.65 и $13.2 \mathrm{~N} / \mathrm{s}^{-1 \mathrm{~kg} M м}$ код девојчица, за леву и десну шаку, респективно (Табела 2). Резултати ANOVE су показали да не постоји статистички значајна разлика између поменутих релативних карактеристика експлозивности у односу на пол (Табела $3, \mathrm{RFDF}_{\text {max }} \check{S}_{\text {SMм }}$ - $\mathrm{F}$ value $=0.10, \mathrm{p}=0.750 ; \mathrm{RFDF}_{\max } \check{S}_{\mathrm{SMM}}-\mathrm{F}$ value $=0.03, \mathrm{p}=0.858)$. Утврђено је да су испитанице за десну шаку оствариле $0.95 \mathrm{~N} / \mathrm{s}^{-1 \mathrm{kgSMM}}$ мање парцијализоване вредности опште експлозивне јачине у односу на дечаке, при чему је ниво IPD достигао вредност 91.81\%, док су парцијализоване вредности остварене код стиска десне шаке веће за $0.49 \mathrm{~N} / \mathrm{s}^{-1 \mathrm{kggmM}}$ него код дечака, уз IPD од $103.69 \%$ (График 2). Наведени резултати указују да се након парцијализације у односу на чисту мишићну масу, тј. SMM разлике између полова у односу на 
општу експлозивну јачине (силу) мишића прегибача прстију леве и десне шаке губе, односно налазе се у сумарном интервалу IPD од 97.75\%.

Код мишића опружача леђно-слабинске мускулатуре (тест мртво вучење) код дечака је измерена просечна вредност $\mathrm{RFDF}_{\max } \mathrm{MRT}_{\text {SMм }}$ на нивоу од $25.93 \mathrm{~N} / \mathrm{s}^{-1 \mathrm{kgSMM}}$ док је код девојчица била $22.31 \mathrm{~N} / \mathrm{s}^{-1 \mathrm{kggmM}}$. Када су у питању мишићи опружачи ногу (тест опружање ногу), измерена релативна вредност опште експлозивне јачине је била на нивоу од $28.68 \mathrm{~N} / \mathrm{s}^{-1 \mathrm{kgSMM}}$ код дечака и 27.05 $\mathrm{N} / \mathrm{s}^{-1 \mathrm{kgSMM}}$ код девојчица (Табела 2). Резултати ANOVE су показали да код оба теста не постоји статистички значајна разлика између поменутих релативних карактеристика експлозивности у односу на пол (Табела 3, $\mathrm{RFDF}_{\text {max }} \mathrm{MRT}_{\text {SMM }}$ - F value $=0.59, \mathrm{p}=0.457 ; \mathrm{RFDF}_{\max } \mathrm{NOGE}_{\mathrm{SMM}}-\mathrm{F}$ value $=0.6$, $\mathrm{p}=0.806)$. Тестиране девојчице су код овог теста оствариле $3.62 \mathrm{~N} / \mathrm{s}^{-1 \mathrm{kgSmM}}$ мање релативне вредности опште експлозивне јачине (силе), при чему je IPD достигао ниво од $86.04 \%$, односно дечаци су у датом тесту остварили за $1.63 \mathrm{~N} / \mathrm{s}^{-1 \mathrm{kgsMM}}$ бољи резултат у односу на девојчице, уз IPD од $94.32 \%$, респективно (График 2). У том смислу, може се рећи да су дечаци код опружача леђно-слабинске мускулатуре, посматрано са аспекта релативних вредности, остваривали за око $1 / 6$ боље резултате у односу на девојчице, док су парцијализовани резултати код опружача ногу веома слични.

Резултати парцијализованих вредности опште експлозивне јачине (силе) за опружаче скочног зглоба (тест плантарна флексија седећи) су показали да је она код дечака на нивоу од $61.85 \mathrm{~N} / \mathrm{s}^{-1 \mathrm{kgSMM}}$ a $82.80 \mathrm{~N} / \mathrm{s}^{-1 \mathrm{kgsMM}}$ код девојчица (Табела 2). ANOVA је показала да не постоји статистички значајна разлика између поменутих релативних карактеристика експлозивности у односу на пол (Табела 3 , $\mathrm{RFDF}_{\max }$ LIST $_{\text {SMM }}-\mathrm{F}$ value $\left.=0.259, \mathrm{p}=0.620\right)$. Ипак, на овом тесту девојчице су оствариле просечно $20.95 \mathrm{~N} / \mathrm{s}^{-1 \mathrm{kgsmm}}$ веће резултате при чему је вредност IPD на нивоу $133.82 \%$. Другим речима, девојчице су код теста плантарна флексија седећи, посматрано са аспекта вредности парцијализованих у односу на масу скелетних мишића (SMM), оствариле за око 1/3 боље резултате од дечака.

Достигнута развијеност специфичне експлозивне јачине (силе) тј. варијабли ( $\left.\mathrm{RFD}_{\max }\right)$, код мишића прегибача прстију шаке (тест стисак шаке) била је на нивоу просечне вредности од 2253.89 и $2369.22 \mathrm{~N} / \mathrm{s}$, за леву и десну шаку код дечака и
990.67 и 1177.33 N/s код девојчица, респективно (Табела 2). У односу на парцијализоване вредности остварени резултати су били на нивоу од од 61.85 и $64.80 \mathrm{~N} / \mathrm{s}$, за леву и десну шаку код дечака и 36.90 и $43.36 \mathrm{~N} / \mathrm{s}$ код девојчица, респективно (Табела 2). Резултати ANOVE су показали да постоји статистички значајна разлика између поменутих апсолутних карактеристика експлозивности у односу на пол и код апсолутних и код парцијализованих вредности (Табела $3, \mathrm{RFD}_{\max }$ ŠL - F value $=19.44, \mathrm{p}=0.001 ; \mathrm{RFD}_{\max } \check{S}^{\mathrm{S} D}-\mathrm{F}$ value $=11.68$, $\mathrm{p}=0.005 ; \mathrm{RFD}_{\text {max }} \check{S}_{\mathrm{SMM}}-\mathrm{F}$ value $=22.949, \mathrm{p}=0.000$; $\mathrm{RFD}_{\max } \check{S}_{\text {SMM }}-\mathrm{F}$ value $=13.17, \mathrm{p}=0.003$ ).

На основу приказаних резултата утврђено је да су дечаци на датом тесту остварили $1263.22 \mathrm{~N} / \mathrm{s}$ боље резултате код леве шаке, односно 1191.89 $\mathrm{N} / \mathrm{s}$ код десне шаке, те да је вредност IPD 43.95\% и $49.69 \%$, респективно. У том смислу, може се рећи да су резултати дечака више него дупло већи у односу на девојчице.

Код мишића опружача леђно-слабинске мускулатуре (тест мртво вучење) измерна је просечна вредност специфичне експлозивне јачине на нивоу од $6231.00 \mathrm{~N} / \mathrm{s}$ код дечака и 3322.33 N/s код девојчица (Табела 2). Резултати ANOVE су показали да не постоји статистички значајна разлика између поменутих апсолутних карактеристика експлозивности у односу на пол (Табела $3, \mathrm{RFD}_{\max } \mathrm{MRT}-\mathrm{F}$ value $=3.48, \mathrm{p}=0.087$ ), односно да је разлика на граничном нивоу за вероватноћу од $90.0 \%$. Апсолутна математичка разлика измерених резултата дате варијабле је 2908.67 N/s y корист дечака, те вредност IPD од $53.31 \%$ указују на чињеницу да су и у случају ове мишићне групе, дечаци остваривали приближно дупло веће резултате у односу на девојчице.

Код мишића опружача ногу (тест опружање ногу) измерена је просечна вредност специфичне експлозивне јачине (силе) на нивоу од $4919.67 \mathrm{~N} / \mathrm{s}$ и $2298.00 \mathrm{~N} / \mathrm{s}$ код дечака и девојчица, респективно (Табела 2). Резултати ANOVE су показали да постоји статистички значајна разлика између поменутих апсолутних карактеристика експлозивности у односу на пол (Табела $3, \mathrm{RFD}_{\max }$ NOGE - F value $=13.38, \mathrm{p}=0.003)$. Са аспекта апсолутних показатеља, дечаци су остварили просечно за $2621.67 \mathrm{~N} / \mathrm{s}$ боље резултате, при чему је IPD био на нивоу $46.71 \%$. Другим речима, и у овом случају остварена разлика указује на приближно дупло боље резултате код дечака. 
Код мишића опружача скочног зглоба (тест плантарна флексија седећи) код дечака је измерна просечна вредност специфичне експлозивне јачине (силе) на нивоу од $12314.40 \mathrm{~N} / \mathrm{s}$ a 8840.33 N/s код девојчица (Табела 2). Резултати ANOVE су показали да између ових резултата постоји статистички значајна разлика (Табела $3, \mathrm{RFD}_{\text {max- }}$ LIST - F value $=8.183, \mathrm{p}=0.014$ ). Девојчице су оствариле нижи ниво апсолутне вредности специфичне експлозивне јачине за 3474.07 N/s, уз остварен ниво IPD од 71.78\% (График 1). Другим речима, постигнуте вредности $\mathrm{RFD}_{\text {max }}$ код девојчица су биле на 2/3 вредности дечака.

Код мишића опружача леђно-слабинске мускулатуре (тест мртво вучење) код дечака је измерена просечна парцијализована вредност специфичне експлозивности од $167.75 \mathrm{~N} / \mathrm{s}^{-1 \mathrm{~kg} M м}$ а код девојчица од $124.91 \mathrm{~N} / \mathrm{s}^{-1 \mathrm{kggmM}}$ (Табела 2). Резултати ANOVE су показали да не постоји статистички значајна разлика у односу на пол (Табела $3, \mathrm{RFD}_{\max } \mathrm{MRT}_{\text {SMM }}-\mathrm{F}$ value $\left.=1.765, \mathrm{p}=0.209\right)$ иако су девојчице датог узраста оствариле мањи ниво специфичне експлозивности за $42.84 \mathrm{~N} / \mathrm{s}^{-1 \mathrm{kgSMM}}$, уз достигнути ниво IPD од 74.45 \% (График 2). Специфични ниво експлозивности мишића опружача леђно-слабинске мускулатуре парцијализован је у односу на масу скелетних мишића (SMM), код девојчица се налазио на око 3/4 у односу на резултате измерене код дечака.

Код мишића опружача ногу (тест опружање ногу) парцијализовна вредност специфичне експлозивне јачине код дечака је била на нивоу од $136.42 \mathrm{~N} / \mathrm{s}^{-1 \mathrm{kgSMM}}$, и $86.34 \mathrm{~N} / \mathrm{s}^{-1 \mathrm{kgSMM}}$ код девојчица (Табела 2). Између ових резултата је утврђена статистички значајна разлика (Табела $3, \mathrm{RFD}_{\max }$ NOGE $_{\text {SMM }}-\mathrm{F}$ value $\left.=6.95, \mathrm{p}=0.022\right)$. Као и у случају мишића леђно-слабинске мускулатуре, и код мишића опружача ногу, девојчице су оствариле мањи релативни ниво вредности варијабле за $50.08 \mathrm{~N} / \mathrm{s}^{-1 \mathrm{kgSMM}}$, уз достигнути IPD од $63.29 \%$ (Графикон 2). И у случају ове мишићне групе код девојчица је релативна вредност специфичне експлозивности била приближно $2 / 3$ у односу на резултате измерене код дечака.

Просечна вредност специфичне експлозивне јачине опружача скочног зглоба (тест плантарна флексија седећи) је била $341.04 \mathrm{~N} / \mathrm{s}^{-1 \mathrm{kggMM}}$ код дечака, и $319.09 \mathrm{~N} / \mathrm{s}^{-1 \mathrm{kgSMM}}$ код девојчица (Табела 2). Није утврђена статистички значајна разлика између поменутих релативних карактеристика ек- сплозивности у односу на пол (Табела $3, \mathrm{RFD}_{\text {max }}$ $\mathrm{LIST}_{\text {SMM }}-\mathrm{F}$ value $\left.=0.815, \mathrm{p}=0.384\right)$. Девојчице су оствариле мању вредност за $21.95 \mathrm{~N} / \mathrm{s}^{-1 \mathrm{kgSMM}}$, уз достигнути ниво IPD од 93.56\% (Графикон 2). Међутим, у случају ове мишићне групе просечна вредност релативног нивоа специфичне експлозивности мишића опружача скочног зглоба код девојчица је била веома слична вредностима забележеним код дечака.

На основу свега претходно наведеног намеће се закључак да дечаци остварују значајно веће апсолутне вредности опште експлозивне јачине (силе) у односу на девојчице, код свих тестираних мишићних група. Резултати ове студије су показали да се IPD налази у распону од $62.62 \%$ за мишиће леђно-слабинске мускулатуре до $82.52 \%$ за мишиће прегибаче прстију десне (доминантне) шаке. Генерално посматрано, у просеку девојчице су достигле $71.55 \%$ вредности опште експлозивности у односу на дечаке (График 1). Ови резултати су веома слични са претходно публикованим резултатима истраживања које се бавило међуполним разликама у снази различитих мишићних група (Chen et al., 2012), где је утврђено да девојке на генералном нивоу остварују 37-68\% мишићне снаге коју испољавају мушкарци, уз мање резултате остварене код свих тестираних мишићних група. У контексту резултата добијених овим истраживањем, значајно је истаћи чињеницу да су мање међуполне разлике у испољеној снази утврђене код екстензорних мишићних група доњих екстремитета, где девојке остварују резултате на нивоу 65\% вредности резултата које постижу мушкарци (Chen et al., 2012) што, иако се ради о различитим својствима, донекле корелира са налазима ове студије.

Ипак, када се резултати посматрају са аспекта парцијализованих вредности у односу на масу скелетних мишића (SMM), уочене разлике између тестираних дечака и девојчица се драстично смањују, што указује на релативно изједначен контрактилни потенцијал у функцији чисте мишићне масе независно од пола испитаника. У том смислу, индикативне су утврђене вредности укупног IPD (Графикон 2) који за апсолутне вредности износи $71.55 \%$ (IPD RFDF $\left.{ }_{\max -} \mathrm{ALL}\right)$, док се за релативне вредности IPD налази на нивоу $101.98 \%$ (IPD $\left.\mathrm{RFDF}_{\max } \mathrm{ALL}_{\mathrm{SMM}}\right)$. Ово се може објаснити већим процентуалним уделом мишићне масе у телесном саставу код дечака $(\mathrm{PSMM} \%=54.66 \pm 1.42)$ у одно- 


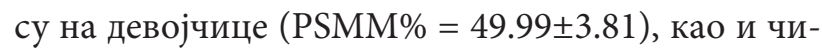
њеницом да девојчице имају мању укупну телесну масу, па самим тим, и апсолутну мишићну масу. Такође, овакви резултати корелирају са претходно утврђеном чињеницом да мушкарци и жене остварују релативно мале разлике RFD у условима вољне контракције (Kent-Braun \& Alexander, 1999) тј. експлозиве јачине (силе) реализоване без укључивања спољашње електростимулације мишића у смислу повећања постигнутог нивоа активације.

Потребно је посебно нагласити да је чак код релативних показатеља опште експлозивне јачине (силе) мишића опружача скочног зглоба (плантарних флексора), утврђено да је IPD на нивоу $133.82 \%$, што указује да су тестиране девојчице просечно постигле чак за 1/3 боље резултате од дечака у датом тесту.

Такође, једно од могућих објашњења за утврђене разлике параметара опште и специфичне мишићне јачине (силе), без обзира на посматрану мишићну групу, односи се на претходно утврђено постојање разлика у заступљености мишићних влакана различитог типа и на разлике у пољу преклапања миофиламената у мишићним влакнима у корист мушкараца (Staron et al., 2000; Kent-Braun \& Alexander, 1999), што би могло условити апсолутно већи потенцијал за испољавање експлозивне јачине код дечака. Као други потенцијални разлог постојања међуполних разлика намећу се утврђене разлике у дистрибуцији контрактилног ткива између горњег и доњег дела тела. Наиме, утврђен је већи процентуални удео контрактилног ткива у доњем делу тела код жена (Janssen et al., 2000), али и процентуално већи удео мишићне масе у телесном саставу код мушкараца, те апсолутно већа маса скелетних мишића код дечака.

Могући разлог, за утврђене постигнуте вредности специфичне експлозивне јачине (силе) мишића прегибача прстију леве и десне шаке, посматрано и са аспекта апсолутних и са аспекта релативних вредности, поред веће дистрибуције мишићне масе у кранијалном делу тела код мушкараца (Janssen et al., 2000), највероватније указују и на присуство специфичне адаптације условљене «џудо тренингом» с обзиром на чињеницу да су утврђене апсолутне вредности RFD на нивоу 4623.1 N/s за леву и десну шаку збирно. Ранијом студијом (Marković et al., 2016) утврђене су просечне апсолутне вредности специфичне експлозивне јачине (силе), испитиване код одраслих тренираних рвача и умерено активних испитаника, на нивоу 5197.6 N/s и 4040.4 N/s, за обе шаке збирно. На основу поређења тих резултата са резултатима овог истраживања, може се тврдити да џудисти кадетског узраста у датом тесту постижу резултате на нивоу $88.94 \%$ у односу на одрасле рваче и $114.42 \%$ у односу на одрасле умерено активне испитанике, што се може тумачити као директан утицај «џудо тренинга».

\section{ЗАКЉУЧАК}

Циљ овог рада сагледава се у дефинисању дескриптивних карактеристика, као и параметара разлика експлозивне јачине (силе) код системски тренираних и селектираних џудиста кадетске узрасне категорије, како са аспекта апсолутних, тако и са аспекта вредности парцијализованих у односу на масу скелетних мишића (SMM). Основни метод примењен у истраживању је био метод лабораторијског тестирања, применом тензиометријских сонди. Узорак испитаника се састојао од 14 такмичара кадетске категорије у џудо спорту, и то 10 мушкараца и 4 девојке. Експлозивна јачина је анализирана у односу на општу (RFDF $\left.{ }_{\max }\right)$ и специфичну $\left(\mathrm{RFD}_{\max }\right)$ димензију, док су тестиране следеће мишићне групе: прегибачи прстију леве (ŠL) и десне шаке (ŠD), опружачи леђно-слабинске мускулатуре (MRT), опружачи ногу (NOGE) и опружачи скочног зглоба (плантарни флексори, LIST).

На основу добијених резултата се може тврдити да постоји генерална статистички значајна разлика тестираних џудиста кадетског узраста у функцији пола и то, како између апсолутних вредности варијабли опште и специфичне експлозивне јачине (силе), на нивоу Wilks' Lambda Value 0.000, F=898.61, p=0.000, тако и између парцијализованих (релативних) вредности опште и специфичне експлозивне јачине (силе), на нивоу Wilks' Lambda Value 0.001, F=325.71, p=0.000.

Највећи ниво разлике између пола, а у односу на апсолутне вредности мерене експлозивности, утврђене су код варијабли специфичне експлозивне јачине (силе) и то за леву шаку $\left(\mathrm{RFD}_{\max } \mathrm{ŠL}_{\text {, }}\right.$ $\mathrm{p}=0.001, \operatorname{Eta}^{2}=0.618$, тј. 61.8\%), затим за мишиће опружаче ногу (RFD ${ }_{\text {max }}$ NOGE, $\mathrm{p}=0.003, \mathrm{Eta}^{2}=0.527$, тj. 52.7\%), те за десну шаку (RFD ${ }_{\max } \check{\mathrm{S} D}, \mathrm{p}=0.005$, 
$\mathrm{Eta}^{2}=0.493$, тj. 49.7\%). У односу на парцијализоване вредности варијабли на основу скелетне мишићне масе, највећи ниво разлике је утврђен код варијабли специфичне експлозивне јачине (силе) и то за леву шаку $\left(\mathrm{RFD}_{\max } \check{\mathrm{S}}_{\mathrm{SMM}}, \mathrm{p}=0.000, \mathrm{Eta}^{2}=0.657\right.$, тj. $65.7 \%$ ), па за десну шаку ( $R F D_{\text {max }} \check{S}_{\text {SMM }}, \mathrm{p}=0.003$, $\mathrm{Eta}^{2}=0.523$, тј. 52.3\%) и мишиће опружаче ногу $\left(\mathrm{RFD}_{\max } \mathrm{NOGE}_{\mathrm{SMM}^{\prime}}, \mathrm{p}=0.022, \mathrm{Eta}^{2}=0.367\right.$, rj. $\left.36.7 \%\right)$.

Сумарна вредност индекса полног диморфизма (IPD) за апсолутну општу $\left(\mathrm{RFDF}_{\max }\right)$ и специфичну $\left(\mathrm{RFD}_{\max }\right)$ експлозивну јачину (силу) налази се на нивоу од 71.55 и 53.09\%, што значи да су тестиране девојчице достигле $71.55 \%$ и $53.09 \%$ датих контрактилних карактеристика у односу на тестиране мушкарце. Међутим, када се мерене варијабле парцијализују у односу на SMM, поменуте разлике у функцији пола се смањују на ниво од 101.98 и $71.58 \%$.

Ови резултати су показали да постоје методолошке индиције научне оправданости у односу на парцијализацију резултата експлозивне јачине, као мере развијености контрактилног мишићног потенцијала за што интензивније испољавање мишићне силе у јединици времена, у односу на скелетну мишићну масу, као масе чистог контрактилног ткива у организму. На овај начин се повећава ниво сензитивности саме варијабле у смислу утврђивања реалних функционалних разлика између полова. Претпоставка је да би овај методски поступак парцијализације резултата могао бити и сензитивнији у односу на утврђивање разлика контрактилних способности и у односу на остале критерије, као што су: узраст, такмичарска ефикасност, тренажни период итд.

\section{ЛИТЕРАТУРА}

1. Chen. G., Liu, L., Yu J. (2012). A comparative study on strength between american college male and female students in caucasian and asian populations. Sport science review 21(3-4), 153-165.

2. Detanico, D., Budal Arins, F., Dal Pupo, J., \& Dos Santos, S. G. (2012). Strength parameters in judo athletes: an approach using hand dominance and weight categories. Human Movement, 13(4), 330-336.

3. Dopsaj, M. (2015). Analitika i dijagnostika u sportu i fizičkom vaspitanju. (CD-ROM). Fakultet sporta i fizičkog vaspitanja, Beograd.
Генерално посматрано, резултати овог истраживања предстаљају иницијалне квантитативне вредности мерених контрактилних карактеристика, који могу послужити као почетни стандарди у функцији евалуације и дефинисању квалитативних оцена за процену нивоа припремљености спортиста, што ће све сумарно утицати на повећање опсега знања у систему припреме младих џудиста, односно усавршиће постојећу технологију спортске припреме џудо спорта.

\section{ОГРАНИЧЕЊА СТУДИЈЕ}

Ово истраживање је спроведено на релативно малом узорку испитаника, који се састојао од 10 џудиста и 4 џудисткиње, чланова кадетске тренажне селекције истог клуба. Ово донекле умањује могућност генерализације налаза и указује на потребу за даљим систематским истраживањем карактеристика експлозивне мишићне јачине (силе), и мишићне јачине уопште, уз укључивање већег броја испитаника у узорак.

\section{ЗАХВАЛНОСТ}

Овај рад је део пројекта "Ефекти примењене физичке активности на локомоторни, метаболички, психосоцијални и васпитни статус популације Републике Србије”, број III47015, финансираног од стране Министарства просвете, науке и технолошког развоја Република Србија - научни пројекти, циклус 2011 - 2018.

4. Dopsaj, M., Ilić, V., Đorđević-Nikić, M., Vučković, M., Eminović, F., Macura, M., \& Ilić, D. (2015). Descriptive model and gender dimorphism of body structure of physically active students of Belgrade University: Pilot study. Anthropologist, 19(1), 239-248.

5. Dopsaj, M., Koropanovski, N., Vučković, G., Blagojević, M., Marinković, B., \& Miljuš, D. (2007). Maximal isometric hand grip force in well-trained university students in Serbia: Descriptive, functional and sexual dimorphic model. Serbian Journal of Sports Sciences, 1(4), 138-147. 
6. Dopsaj, M., Milošević, M., Blagojević, M. (2000). Analysis of the reliability and factoral validity of selected muscle force mechanical characteristics during isometric multi joint test. U Y. Hong, D.P. Johns (ur.), Proceedings of XVIII international simposium on biomechanics in sport, (str. 146149). Hong Kong: Department of sports science and physical education - The Chinese University of Hong Kong.

7. Dopsaj, M., Milošević, M., Vučković, G., Blagojević, M. (2001) Metrological values of the test to assess mechanical characteristics of maximal isometric voluntary knee extensors muscle force from standing position. NBP-Nauka Bezbednost Policija, 6(2), 119-132.

8. Dopsaj, M., Thanopoulos, V., Race, V., Okičić, T. (2004). The relationship between competitive fitness levels in top sprinters swimmers at 50 and $100 \mathrm{~m}$ freestyle and indicators of explosiveness of different muscle groups: A result prediction model. $4^{\text {th }}$ International Conference on Strength Training: Book of Abstracts, Edited by: Kellis, E., Amiridis, I. and Vrabas., I., Aristotle University of Thessaloniki, Department of Physical Education and Sport Science at Serres pp. 153 - 154, Serres, Greece.

9. Franchini, E., \& Sterkowicz, S. (2000). Techniques used by judoists during the World and Olympic tournaments 1995-1999. Human Movement, 2(2), 23-33.

10. Franchini, E., Del Vecchio, F. B., Matsushigue, K. A., \& Artioli, G. G. (2011). Physiological profiles of elite judo athletes. Sports Medicine, 41(2), 147166.

11. Franchini, E., Nunes, A. V., Moraes, J. M., \& Del Vecchio, F. B. (2007). Physical fitness and anthropometrical profile of the Brazilian male judo team. Journal of Physiological Anthropology, 26(2), 59-67.

12. Ilić, V., Mudrić, M., Kasum, G., Ćirković, M., Gavrilović, D. (2012). Morphological and motor characteristics of young judokas. Fizička Kultura, 66(2), 110-118.
13. Janssen, I., Heymsfield, S. B., Wang, Z., \& Ross, R. (2000). Skeletal muscle mass and distribution in 468 men and women aged $18-88$ yr. Journal of Applied Physiology, 89(1), 81-88.

14. Kent-Braun, Jane A., \& Alexander V. Ng. (1999). Specific strength and voluntary muscle activation in young and elderly women and men. J. Appl. Physiol. 87(1): 22-29.

15. Koprivica, V. (2013). Teorija sportskog treninga. SIA: Beograd.

16. Marković, M., Dopsaj, M., Kasum, G. (2016). Differences between contractile characteristics of wrestler's hand and control group of young, moderately active people. U S. Pantelić (ur.), Fis communications book of proceedings, (str. 44-53). Niš: FSFV - Univerzitet u Nišu.

17. Monteiro, L. (2016). Analysis of rate force development, power and resistance explosive strength indicators in top elite vs. elite male judokas. U H. Sertić, S. Čorak i I. Segedi (ur.). Applicable Research in Judo Proceedings book, (str. 36-39). Poreč:Faculty of kinesiology - University of Zagreb.

18. Monteiro, L., Chambel, L., \& Cardoso, M. (2011). Elite and sub-elite judokas: the factors behind international success.U A.A. Figueiredo i C. Gutierrez-Garcia (ur.). Scientific congress on martial arts and combat sports, proceedings (str.73-76). Viseau:Instituto politecnico de Viseau.

19. Staron, R. S., Hagerman, F. C., Hikida, R. S., Murray, T. F., Hostler, D. P., Crill, M. T., \& Toma, K. (2000). Fiber type composition of the vastus lateralis muscle of young men and women. Journal of Histochemistry \& Cytochemistry, 48(5), 623-629.

20. Tanner, R., Gore, C. (2013). Physiological Tests for Elite Athletes (Sec. Ed.). Australian Institute of Sport. Champaign, IL: Human Kinetics, pp.212.

21. Thomas, S. G., Cox, M. H., LeGal, Y. M., Verde, T. J., \& Smith, H. K. (1989). Physiological profiles of the Canadian National Judo Team. Canadian Journal of Sport Sciences = Journal Canadien des Sciences du Sport, 14(3), 142-147. 


\title{
FUERZA (POTENCIA) EXPLOSIVA DE DISTINTOS GRUPOS MUSCULARES DE LOS JUDOCAS DE EDAD DE CADETE EN LA FUNCIÓN DEL SEXO
}

\begin{abstract}
Resumen
El objetivo del presente trabajo es establecer la diferencia entre la fuerza (potencia) explosiva en judocas varones y judocas hombres de la edad de cadete. Los resultados de las capacidades contráctiles medidas se obtuvieron aplicando las baterías de pruebas estándar, utilizando el método de dinamometría isométrica, para los cinco grupos musculares como sigue: el músculo flexor de dedos de las manos izquierda y derecha, el extensor de la musculatura dorsal-lumbar, el extensor de piernas y extensor de tobillo. La medición abarcó una muestra de 14 examinados y examinadas en total que compitieron en el sistema del campeonato nacional individual de la República de Serbia para la determinada edad. Sobre la base de los resultados obtenidos se puede afirmar que existe una diferencia general estadísticamente considerable de los judocas examinados en función del sexo, tanto entre los valores absolutos de las variables de fuerza (potencia) explosiva general y específica, en el nivel Wilks' Lambda Value 0.000, F=898.61, p=0.000, como también entre los valores parcializados (relativos) de las variables medidas en el nivel Wilks' Lambda Value 0.001, $\mathrm{F}=325.71, \mathrm{p}=0.000$. El mayor nivel de diferencia entre los sexos y en relación con los valores absolutos, se estableció en las variables de la fuerza (potencia) explosiva específica en la mano izquierda (RFDmax_MI, $\mathrm{p}=0.001$ ), para los músculos extensores de piernas (RFDmax_PIERNAS, $\mathrm{p}=0.003$ ), así como también para la mano derecha (RFDmax_MD, $\mathrm{p}=0.005)$. En relación con los valores parcializados de las variables sobre la base de la masa muscular de esqueleto (MME), el mayor nivel de diferencia se estableció en las variables de la fuerza (potencia) explosiva específica para las manos izquierda y derecha, respectivamente (RFDmax_MIMME, $\mathrm{p}=0.000$; RFDmax MDMME, $\mathrm{p}=0.003$ ). El valor sumado del índex de dimorfismo sexual (IDS) para la fuerza (potencia) explosiva absoluta general (RFDFmax) y específica (RFDmax) está en nivel de 71.55 y $53.09 \%$, lo que significa que las muchachas examinadas alcanzaron $71.55 \%$ y $53.09 \%$ de las características contráctiles dadas en relación con los muchachos examinados. Sin embargo, parcializando las variables medidas en relación con la MME, las diferencias mencionadas en función del sexo disminuyen al nivel de 101.98 y 71.58\%. Observando generalmente, los resultados obtenidos demostraron que existen las indicaciones metodológicas de justificación científica en relación con la parcialización de los resultados de la fuerza explosiva, como medida del desarrollo de la potencialidad muscular contráctil para la expresión más intensa de la potencia muscular por unidad de tiempo en relación con la masa muscular de esqueleto.
\end{abstract}

Palabras claves: JUDO/ CADETES / DINAMOMETRÍA ISOMÉTRICA / FUERZA (POTENCIA) EXPLOSIVA

Примљен: 04. 05. 2017

Прихваћен: 07. 12. 2017 